\title{
TESSITURAS (OU HIBRIDAÇÕES) PARA UMA AUTOBIOGRAFIA
}

\author{
WEAVING (OR HYBRIDIZATION) TO AN AUTOBIOGRAPHY \\ TESITURAS (O HIBRIDACIONES) PARA UNA AUTOBIOGRAFÍA
}

RESUMO: Este texto, ou melhor, este tecido - para manter afiliação a Barthes - teceu suas urdiduras e tramas na tentativa de responder aos editores da Revista Pedagógica da UNOCHAPECÓ que solicitaram ao autor uma autobiografia. Buscou-se, num limitado número de páginas, evocar uma trajetória de 55 anos ininterruptos em sala de aula, como professor e pesquisador. Amealharam-se algumas memórias a alguns trechos de artigos, de livros e de entrevistas com a pretensão de que os mesmos autobiografem o autor. Assim, para marcar um pouco a trajetória da vida acadêmica, foram selecionadas excertos de entrevistas concedidas mais recentemente, visando trazer facetas do cotidiano, no sentido de contribuir com reflexões sobre o "pensamento pedagógico da região sul" e, assim, participar, juntamente com outros intelectuais, numa tentativa de hibridização memorialista. Para tal foram trazidos alguns fragmentos de livro de memórias do autor, excertos de seu blogue e aditou-se algo de sua "Fortuna crítica". Para trazer informações mais direcionadas e pontuais, foram aproveitadas respostas (atualizadas) de entrevista concedida, em 2013, para um Grupo de Pesquisa Formação de Professores.

Palavras-chave: Autobiografia. Blogues. Diários. Educação no Brasil. Memórias de professor.

ABSTRACT: This paper - or to keep the association with Barthes, this cloth - weaved its way through an endeavor to answer the request from UNOCHAPECÓ Pedagogical Magazine's editors of an autobiography. In a few pages the 55 years incessant classroom trajectory, as professor and researcher, were brought to live by memories and quotes from articles, books and recent interviews, seeking to present reflections about the "pedagogical thinking in South (Brazil)" uniting intellectuals in an attempt to memorialist hybridization. Mentioning by name the material, the author's memory book, his blog and an interview performed in 2013 to a Professor's Formation Research Group were used.

Keywords: Autobiography. Blogs. Diaries. Brazilian Education. Professor's memories.

RESUMEN: Este texto, o mejor, este tejido - para mantener afiliación a Barthes - tejió sus enredos y tramas en la tentativa de contestar a los editores de la Revista Pedagógica de la UNOCHAPECÓ que solicitaron al autor una autobiografía. Se pretendió, en un limitado número de páginas, evocar una trayectoria de 55 años impartiendo clases continuamente, como profesor e investigador. Se acumularon algunas memorias y extractos de artículos, de libros, de entrevistas con la intención de que los mismos aseguren la autobiografía del autor. Así, para marcar un poco la trayectoria de vida académica, se seleccionó extractos de entrevistas concedidas, más recientemente, visando traer facetas del cotidiano, con la intención de contribuir con reflexiones acerca del "pensamiento pedagógico de la región sur" y de esta forma participar juntamente con otros intelectuales, de una tentativa de hibridación memorialista. A esto se ha traído algunos fragmentos del libro de memorias del autor, extractos de su blog y se añadió algo de su "fortuna crítica”. Para traer informaciones más direccionadas y puntuales, se aprovechó respuestas (actualizadas) de una entrevista concedida en 2013 para un Grupo de Investigación de Formación de Profesores.

Palabras clave: Autobiografía. Blog. Diarios. Educación en Brasil. Recuerdos del profesor. 


\begin{abstract}
* Orientador de doutorado na Rede Amazônica de Educação em Ciências e Matemática (REAMEC). Professor e Pesquisador do Centro Universitário Metodista IPA. Foi Professor Titular da FAPA, PUCRS, UFRGS (quando foi Diretor do Instituto de Química e Coordenador do Curso de Química), ULBRA e UNISINOS (então, coordenador do Programa de Pós-Graduação em Educação), URI e UNILASALLE. Como docente, envolve-se com o Ensino de Ciências e a História da Ciência, com experiência nos níveis Fundamental, Médio e Superior.
\end{abstract}

${ }^{1}$ Leonard Mlodinow (CHICAGO, 1954) é um físico, autor de livros de divulgação científica estadunidense, escreve uma coluna para o New York Times. Seus pais foram ambos sobreviventes do holocausto, e se conheceram em Nova York depois da guerra. Seu pai, que esteve mais de um ano no campo de extermínio de Buchenwald, foi um líder da resistência judaica na sua cidade natal, Częstochowa, na Polônia. Leonard é casado e pai de três crianças, umas delas é uma menina adotada na China. Ele estava no World Trade Center, no dia 11 de setembro de 2001, e sobreviveu ao ataque terrorista. É autor, conjuntamente com Stephen Hawking de $A$ Briefer History of Time (em português: Brevíssima História do Tempo), um best-seller internacional que foi traduzido em 25 idiomas. Um de seus livros que tem como título: O Andar do Bêbado é um tratado sobre o poder do acaso em áreas da nossa vida que vão de jogar futebol, conseguir emprego e receber um diagnóstico médico.

\footnotetext{
${ }^{3}$ Apropriei-me de citação de Olívio Dutra, em "Cevar o Mate" Zero Hora, Opinião, Porto Alegre, 21 set. 2015.
}

\author{
"É raro haver provas do que realmente aconteceu. \\ Na maioria dos casos, nunca saberemos \\ o quanto nossas lembranças são realmente precisas”.
}

$\left(\right.$ MLODINOW $^{1}, 2013$, p. 68)

\section{INTRODUÇÃO}

Há um tempo recebi uma atenciosa mensagem: "Prezado professor Attico Chassot, temos imensa honra de convidá-lo para que escreva um texto autobiográfico para o dossiê Pensamento Pedagógico da Região Sul: recuperando biografias, autobiografias, legados e contributos para a educação brasileira. O convite surgiu, principalmente, quando lemos o seu belo livro Memórias de um professor. Um forte abraço e ficamos esperando seu retorno. Abraços, Maurício Roberto da Silva e Maria de Lourdes Bernartt, Editores da Revista Pedagógica Unochapecó”.

Eram dias atabalhoados, como soa ser o cotidiano da intelectualidade. Já havia dívidas prementes: um artigo para os 20 anos de Química Nova na Escola, revista da qual fui cofundador; duas viagens de ida e volta em 10 dias, uma a Iguatu no árido Ceará e outra a Paus dos Ferros nos confins do Rio Grande do Norte. Tinha os argumentos para dizer não. Mas... eu não sei dizer não. Isto já é uma informação autobiográfica. Escrevi à Maria de Lurdes e ao Maurício dizendo sim. Dias depois referi ao Maurício que cumpriria minha tarefa fazendo uma tessitura com alguns textos. Tenho a pretensão de que os mesmos me autobiografem.

Tento, aqui e agora, cumprir a promessa. Amealho escrevinhares que talvez reflitam alguma contribuição ao pensamento pedagógico da Região Sul, de quem neste ano de 2015, que já se avizinha do ocaso, completa 55 anos ininterruptos em sala de aula. Claro que obliterei algumas passagens, pois "olvidar lo malo también es tener memoria"3.

Fundamentalmente, trago para participar da formação de uma tentativa de hibridização memorialista: alguns fragmentos de meu livro de memórias (CHASSOT, 2012a), excertos de meu blogue, algo de minha "Fortuna crítica" e um texto ainda no index. Faço anteceder, para trazer informações mais direcionadas e pontuais, respostas (atualizadas) a uma entrevista concedida, em 2013, para o Grupo de Pesquisa Formação de professores, ensino e avaliação UNISINOS/CNPq coordenado pela Prof ${ }^{a}$. Dra. Maria Isabel da Cunha.

Para facilitar minha abertura escolhi uma das entrevistas "mais acadêmicas" que concedi, mais recentemente. Há outras que contam mais do cotidiano que não colaborariam para inferências acerca do "pensamento pedagógico da região sul". O italicizado é dos entrevistadores.

1) Estudos que possuem (formação de origem; cursos de pós-graduação etc.): Acredito que a abertura de meu Currículo Lattes seja uma síntese adequada: "Professor há 
53 anos (desde 13 de março de 1961), é licenciado em Química (UFRGS) e mestre e doutor em Educação (UFRGS). Fez pós-doutoramento na Universidade Complutense de Madri. Foi professor titular da PUC-RS, FAPA, UFRGS (onde foi coordenador do Curso de Química e diretor do Instituto de Química) ULBRA, UNISINOS (onde foi Coordenador do Mestrado e Doutorado em Educação), Universidade Regional Integrada do Alto Uruguai e das Missões (URI) no Campus de Frederico Westphalen e Centro Universitário La Salle, em Canoas. Foi professor visitante na Aalborg Universitete na Dinamarca. Foi coorientador em processo de cotutela na Universidade de Lyon 2. É professor e pesquisador do Mestrado Profissional de Reabilitação e Inclusão do Centro Universitário Metodista - IPA e Professor-pesquisador do Programa de Pós-Graduação em Educação, Orientador de doutorado na REAMEC - Rede Amazônica Ensino de Ciência. É autor de vários livros, dos quais sete estão ainda em circulação: A ciência através dos tempos (Moderna, 1994, 23. ed., 2011). Para que(m) é útil o ensino? (EDULBRA, 1995, 2. ed., 2004);Alfabetização científica: questões e desafios para a educação (EDUNIJUI, 2000, 6. ed., 2014); A Ciência é masculina? É sim, senhora! (EDUNISINOS, 2002, 7. ed., 2015); Educação consciência (EDUNISC, 2003, 2. ed., 2007); Sete escritos sobre Educação e Ciências (CORTEZ, 2007); e Memórias de um professor: hologramas desde um trem misto (EDUNIJUí, 2012). Tem nos livros e no escrever duas de suas paixões. É conectado ao mundo internético onde mantém um blogue atualizado: Mestrechassot.blogspot.com. Tem sido convidado como palestrante em todos os estados brasileiros e em alguns países. Mais detalhes em <www.professorchassot.pro.br $>$.

Ano em que iniciou a carreira de docência universitária: 1965, lecionando Química, no curso de História Natural da Faculdade de Filosofia Ciências e Letras, geratriz da UNISINOS.

Tempo de serviço na universidade: Desde 1965 tive vínculo trabalhista com UNISINOS (1965/1966); PUC (1966/1981); FAPA (1968/1973); UFRGS (1967/1991); ULBRA(1992/1996) e mais uma vez UNISINOS 1995/2006); URI (2011/2015) e Unilasalle (cinco meses em 2013). Em exercício: Centro Universitário Metodista IPA (desde 2006).

2 O INÍCIO DA CARREIRA COMO PROFESSOR

\subsection{Conta-nos, um pouco, de sua vida universitária, como começou, porque se decidiu por ela:}

Concluí o $3{ }^{\circ}$ científico em dezembro de 1960 e em fevereiro de 1961 fiz dois vestibulares para a Engenharia da UFRGS e fui reprovado em ambos; retorno a Montenegro para voltar a morar na casa de meus pais e procurar empre- 
go. O quase acaso me faz professor. Este frutuoso acaso é capítulo de Memórias de um professor: hologramas desde um trem misto.

\subsection{Com que percurso:}

Iniciei em 13 de março de 1961, como Professor de Matemática no $3 .^{\circ}$ científico e na $1 .^{\mathrm{a}}$ e na $2 .^{\mathrm{a}}$ série ginasial) e Ciências Naturais (na $3^{\mathrm{a}}$ e na $4^{\mathrm{a}}$ séries ginasial e na $1 .^{\mathrm{a}}$ série do curso de magistério) do Colégio e Escola Normal Jacob Renner de Montenegro. Obtenho o registro como Professor de Matemática em julho de 1961, por meio de curso de proficiência pelo CADES/MEC. Entre 1962/1969 fui professor de Química em Colégios de Montenegro, São Leopoldo (São José e Pedro Schneider) e Porto Alegre (Concórdia, Israelita e Julio de Castilhos) Em Porto Alegre também em Cursos pré-vestibulares (CADFR-Cursinho da Filosofia, IPV e Arquimedes).

\subsection{Como professor universitário, desde 1965 , lecionando na: UNISINOS Química Geral no curso de História Natural}

PUC-RS - Química Orgânica III e IV no curso de Química e Faculdade de Educação. Prática de Ensino no Curso de Química

FAPA - Química Geral no Curso de Matemática.

UFRGS - Inicialmente professor de Química Geral na Faculdade de Filosofia; com a Reforma passa para o Instituto de Química, ocupou todos os postos da carreira docente, nos quais lecionou as disciplinas de Química Geral, Evolução da Química e Transposição de Conteúdos aposentou-se como Professor Titular, posto conseguido através de Concurso Público de Provas e Títulos. Foi Vice-diretor e Diretor do Instituto de Química. Enquanto professor do Instituto de Química lecionou Prática de Ensino de Química na Faculdade de Educação.

ULBRA - Professor de Legislação e Ética Profissional para químicos, Prática de Ensino para as Licenciaturas em Biologia, Matemática e Química e História da Ciência.

UNISINOS - Professor do Centro de Ciências Humanas lecionando Filosofia da Ciência e Práticas de Aprendizagens no Ensino de Ciências em cursos de graduação e com atividades de ensino e pesquisa no Curso de Mestrado e de Doutorado no Programa de Pós-Graduação em Educação.

URI Frederico Westphalen - com atividades de ensino e pesquisa no Programa de Pós Graduação em Educação.

UNILASALLE - com atividades de ensino e pesquisa no Programa de Pós Graduação em Educação.

Em exercício:

Centro universitário metodista do IPA, graduação, disciplinas para licenciaturas de Políticas para Educação Brasileira, Didática, Conhecimento, Linguagem, 
Aprendizagem e conhecimento, Teorias do Desenvolvimento Humano e Ética, Sociedade e Meio Ambiente. E atividades de ensino e pesquisa no Mestrado Profissional de Reabilitação e Inclusão.

\subsection{Como era a universidade no início de sua docência?}

Iniciei como professor universitário em 1965 e em 1968 uma reforma universitária (Lei 5540/68) gestada pelo governo militar redesenhou a Universidade brasileira. A palavra-chave é "departamento". Havia talvez dois ou três professores de Química na Faculdade de Filosofia. Migro para um dos três departamentos do Instituto de Química (Departamento de Química Inorgânica) onde foram lotados professores provenientes da Engenharia, Farmácia, Agronomia, Geologia. No Instituto de Química lecionávamos Química para todos os cursos da Universidade onde havia esta disciplina no currículo. Eu era o mais jovem, cabiam-me as disciplinas que ninguém queria.

\subsection{Que recordações você tem da época em que começou a ensinar?}

As recordações são as melhores: lecionava Química Geral para alunos de três cursos (Engenharia Química, Farmácia e Química) que iniciavam a carreira acadêmica. Em geral, três turmas de mais de 50 alunos. Era muito bom.

\subsection{Que problemas enfrentou?}

O que mais se valorizava era o conteúdo e não se podia "divagar" sobre Ciência, pois havia um programa a cumprir e também porque o regime era de exceção. Encontrou alguma estratégia institucional de apoio a esses primeiros passos? Foi muito significativo ter feito, por iniciativa exclusivamente pessoal, um curso de Metodologia de Ensino Superior. Depois desejei fazer Mestrado em Química de Cristais Líquidos, na UFSC, em Florianópolis. Já tinha até orientador. Afortunadamente o meu departamento não autorizou (alegando não ter quem me substituísse). Fiz então mestrado em Educação sem me afastar (detalhes desta miraculosa troca de rota em Memórias de um professor: hologramas desde um trem misto).

\subsection{Como evoluiu com o passar dos anos?}

Talvez, ter sido "escalado" para dar uma disciplina de História da Química (que ninguém queria dar) tenha decretado minha evolução. Tenho gratidão à disciplina QUI-114- Evolução da Química. Primeiro reconhecia que não podia lecionar História da Química sem saber História da Ciência; depois vi que deveria estudar História da 
Filosofia, das Artes, das Religiões (a mais significativa), das Bruxarias e também a história daqueles que tiveram suas histórias sonegadas ou apagadas. Foi isto que fiz e me facilitou ser professor.

\subsection{Que gostaria de ter encontrado, em sua época, para apoiar seu desenvolvimento profissional docente?}

Um modelo de Pós-graduação como há hoje.

\subsection{Seria essa uma responsabilidade dos pares - professores mais experientes - ou de um setor pedagógico na estrutura acadêmica?}

Talvez dos dois estratos.

\section{A MATURIDADE E A CONSTRUCTO DOS SABERES DOCENTES}

\subsection{Quando diria que alcançou sua maturidade docente?}

Não sei se alcancei. Cada novo semestre parece que estou em março de 1961.

Que fatores foram importantes para alcançar essa condição?

Talvez ter feito o Doutorado em Educação tenha sido ponto de virada.

Que aspectos foram perdendo importância na sua docência e quais as que foram ganhando valor? histórico.

Perde valor o conteúdo e ganha a análise do contexto

Que caracterizava os estudantes no início de sua carreira e que diferenças reconhece neles, na atualidade?

Mesmo que a Escola não tenha mudado (ela foi mudada!) e a Escola do começo do Século 21 seja muito diferente da de hoje, vejo os estudantes muito parecidos. Ver por exemplo: CHASSOT, Attico A Escola mudou ou foi mudada. Pátio, Revista Pedagógica, Porto Alegre, ano XIV, fev./abr. 2010, p 10-13, ISSN 1518-305X.

Quais são/foram as maiores satisfações que marcam/ ram a sua vida universitária?

Ter uma produção escrita com reconhecimento nacional. Tenho livros que circulam há mais de dez anos; um 
deles há 20. Ter estado, como professor (de maneira especial como palestrante), em todas as 27 unidades federativas do Brasil. Em 2014 fiz 74 palestras. Ter estado sempre em sala de aula, mesmo quando o exercício de cargos poderiam me isentar da atividade docente. Ser editor de um blogue há quase 10 anos, com mais de 300 acessos diários.

\subsection{A relação com a pesquisa}

As políticas públicas tem incorporado a pesquisa como prioridade básica da universidade. Em sua opinião, que papel ocupou/deve ocupar a pesquisa na vida acadêmica?

Especialmente fazendo do meu ser professor o objeto de pesquisa.

Como essa posição se constituiu na sua trajetória docente?

Para meus colegas algo menos relevante.

Para muitos colegas, ser um bom docente compete com ser um bom pesquisador. Em seu caso, é/foi fácil compreender e articular a docência e a investigação?

Foi, usualmente, uma pesquisa "menor".

Como esse processo se construiu?

Com artesania.

\subsection{Opinião e valores gerais}

Como percebe o ânimo e a preocupação pelo ensino entre os atuais professores/as universitários/as?

Muitos em contagem regressiva para a aposentadoria. O que pode fazer deles um bom professor?

A crença que ser professor não é apenas profissão, mas também vocação. Eu acredito nisso.

Que estratégias as IES deveriam desencadear na direção de um ensino de qualidade?

As licenciaturas e os Programas de pós-graduação deveriam ser as joias da coroa de qualquer IES. Há que se repensar esta nova Universidade, deslumbrada e prostituída pela tecnologia, da qual se sequestrou todo e qualquer espaço destinado à reflexão. Esta nova universidade avilta- 
da, por ter aderido a fazer de seu produto uma mercadoria, não pode ter uma expectativa de vida muito grande, Ela há de esboroar-se junto com o capitalismo. Escrevo sobre isso em Chassot (2012b).

Como estabelecer essa meta em tempos de democratização do acesso ao ensino superior no Brasil?

Talvez, esse tempo seja privilegiado para tal. Nos últimos semestres, mais da metade (às vezes turmas inteiras) são alunos da primeira geração que chegam à Universidade.

Se dependesse de você, que passos deveria dar a universidade brasileira para enfrentar os desafios do século $X X I$ ?

Definiria políticas nacionais para implementar aquilo que anunciei em 5.2

O que mais você gostaria/poderia discorrer para contribuir com o tema de nossa pesquisa?

Desejo que desta pesquisa emanem produtos que possa converter uma utopia como a que está em 5.2 se transformasse em realidade.

\subsection{Fragmentos de um livro de memórias:}

Em 2012, depois de dificuldades editoriais (vencera um edital em uma Instituição que às vésperas da publicação alegou falta de recursos e simplesmente devolveu os originais) foi publicado Memórias de um professor: hologramas desde um trem misto em comemoração aos meus 50 anos de professor. São 51 capítulos, um para cada ano de 1961 a 2011 num total de 501 páginas. Só com fragmentos deste livro, a começar pela preciosa apresentação de meu colega e amigo Prof. Dr. Jose Clovis de Azevedo, então Secretário de Educação do Rio Grande do Sul, poderia elaborar o texto solicitado. As outras duas fontes anunciadas (Blogues e Fortuna Crítica) parecem mais sumarentas.

Por limitações na extensão deste texto vou trazer apenas três fragmentos. Pode-se imaginar o quanto esta escolha foi difícil, ante o volume de texto que possuo.

\section{7 [Excerto do capítulo: 1961 - Foi dada a partida, p. 25 a 31]}

Mas para começar a contar a história de meu fazer-me professor retorno ao ano de 1957, quando "me formo" no Ginásio São João Batista, uma escola marista, em Montenegro. Os irmãos maristas era mantenedores de Ginásios em muitas cidades do interior, que eram responsáveis pela 
educação masculina. A educação feminina nas escolas católicas era feita em redes mantidas por irmãs, que no curso primário eram mistas. Há um capítulo (1983) em que falo de minha escolarização no primário e no ginásio. Os colégios luteranos eram mistos. Outras denominações religiosas, além de católicos e luteranos, não tinham presença muito significativa com escolas. A existência de colégios públicos para formação secundária era muito rara nas cidades do interior.

Aqui é preciso uma explicação. No começo da segunda metade do século 20, concluir o curso ginasial [então havia cinco anos de curso primário que eram sucedidos por quatro anos de curso ginasial; neste se ingressava por um exame de admissão], especialmente no interior, era motivo de solene formatura. Esta se realizava no melhor clube da cidade e na mesa que presidia a solenidade se assentavam além do diretor do Ginásio, do paraninfo e dos professores homenageados, o prefeito municipal, o vigário da paróquia e comandante do quartel da Brigada Militar.

Formatura no curso ginasial [hoje seria terminar o ensino fundamental] merecia até quadro de formatura, que antes de ir para o panteão da escola ficava exposto na vitrine da principal loja da cidade, bem em frente à praça. Não eram poucos os formandos que passavam a ostentar a partir de então anel de grau.

Na minha formatura, além do diploma havia os que ganhavam uma láurea por bom comportamento e em cada uma das matérias [como se chamavam as disciplinas] havia premiação com medalhas acompanhadas de prêmios, geralmente livros doados pela "forças vivas da sociedade". Sei que recebi três medalhas - fotografias de então mostram que uma menina, talvez de uns seis anos, finamente vestida, trazia as medalhas em uma bandeja, assim como nas Olimpíadas - na memorável noite de 8 de dezembro de 1957. Uma foi em canto orfeônico e recordo ainda o comentário do diretor Irmão Luís Benício, de que eu não merecia o prêmio, pois desafinava até o hino nacional; conquistei-o porquê a prova era teórica e eu sabia responder às perguntas do Manual de Canto Orfeônico, de Luiz do Rego, uma edição FTD. A outra medalha foi de latim. A terceira parece que foi de matemática.

Nunca me esqueço, que uns anos antes de minha formatura, talvez ainda estivesse no primário, quando o meu pai chegou de uma formatura de um filho da D. Adolfina, viúva de um ferroviário colega dele, dizendo que gostaria que um dia um de seus filhos se formasse no ginásio. Todos os sete fizeram isso, quase todos se graduaram na universidade e um deles se fez doutor. Se vivo fosse talvez contasse com orgulho, em 2002, que tinha um filho fazendo pós-doutorado "no estrangeiro!".

Neste ano de 1957, fui a Porto Alegre e fiz seleção para o curso científico do Colégio Estadual Júlio de Castilhos. Assim em 1958, 1959 e 1960 estudei no Julinho. Destes três anos quero destacar uma data. 
Trago minhas evocações do dia 29 de junho de 1958, um domingo. Em 2008, nessa data, eu, como muitos brasileiros evoquei um 29 de junho de 50 anos passado, quando o Brasil ganhou pela primeira vez a Copa do Mundo na Suécia. Não vou comentar esse assunto, pois mereceu, em alguns jornais de então, suplementos especiais, com chamadas de capa, a meu juízo, tintadas de exagero: "o dia que o Brasil foi inserido no mapa-múndi”.

Por ser dia de São Pedro, padroeiro do Estado, desde que o Império conhecia suas terras mais 'surenhas' como Província de São Pedro do Rio Grande do Sul, fora a data escolhida para inauguração do prédio do Colégio Estadual Júlio de Castilhos na Praça Piratini. Desde março já tínhamos aulas nesse local, ainda em fase de acabamento, desprovido de vidraças. Eu era aluno do $1 .^{\circ}$ Científico. Terminara o Ginásio em dezembro, em Montenegro, e vivia o meu primeiro ano de Porto Alegre. As solenidades foram pela manhã, marcadas por missa celebrada pelo arcebispo, entre dois magníficos leões de bronze, que eu aprendera serem os únicos salvados do incêndio que consumira o antigo prédio do Julinho que ficava na João Pessoa, onde é hoje a Faculdade de Economia da UFRGS.

Após a missa voltei de bonde; primeiro da Azenha até a Riachuelo e desta descia a Borges de Medeiros, para na Praça Parobé tomar o bonde São João e chegar à Rua São Pedro com a Eduardo (nome como era conhecida a Avenida Presidente Roosevelt), depois ir até a Rua Ernesto Fontoura, onde ficava o Bar Caçula, local onde eu morava e trabalhava. Então os rádios portáteis eram raros e não lembro que na viagem de quase uma hora houvesse ouvido algo acerca do que ocorria em Estocolmo.

Não recordo muito do jogo. Acompanhávamos por rádio. A Rádio Guaíba, inaugurada no ano anterior, transmitia com esquema considerado inovador. O som ia da Suécia para Suíça e desta para o Rio de Janeiro e daí para Porto Alegre. O locutor era o Mendes Ribeiro que cunhara então um bordão: "Deus não joga, mas fiscaliza!"

À época não havia transmissão por televisão. Na Copa de 1966, no Chile, havia videoteipes vindos de avião, transmitidos 24 anos depois. Recordo em 1958 ter pintado um dístico na vitrine do Bar Caçula, "Brasil Campeão do Mundo". A maior emoção era o surgimento do "Rei Pelé", um ano mais jovem que eu.

No primeiro científico estudei no turno da tarde, trabalhando de manhã no Bar Caçula. No segundo e terceiro anos estudei à noite, trabalhando de dia no Restaurante da Reitoria da UFRGS. Quem fazia o científico tinha usualmente dois destinos: Engenharia ou Medicina. Quem fazia o Clássico, destinava-se ao Direito. Mesmo estudando naquele que era considerado o Colégio Padrão do Estado, não se falava em alternativas, como Agronomia ou mesmo uma Licenciatura.

Terminado os três anos de científico, fiz em janeiro, vestibular na UFRGS para Engenharia. Então se fazia 
vestibular unificado para a Escola de Engenharia e a opção por uma modalidade (Civil, Minas, Química...) acontecia durante o $1 .^{\circ}$ ano. Fui reprovado em desenho. Não consegui desenhar uma parábola, como o exigido, com tinta nanquim. Em fevereiro, na segunda chamada, se repetiu o meu insucesso, pela mesma razão. Fiquei muito frustrado. Não sabia o que fazer. Vi que não havia sentido ficar em Porto Alegre, pois meu emprego servia para pagar o aluguel de um quarto de um apartamento que ficava na Avenida Getúlio Vargas, que eu compartia com o colega de Julinho Omilton Bonotto, que fora aprovado na Medicina.

Em Montenegro procurei sem sucesso algum emprego em escritório de alguma empresa. Em qualquer lugar era descartado por falta de experiência. Minha busca de emprego se dava em uma área que eu há três anos rejeitara. Deixara, então, a cidade porque as duas únicas opções depois de se terminar o ginásio eram curso de magistério, na época exclusivamente feminino; e, técnico em contabilidade, que não estava no horizonte de quem sonhava voar mais alto. Agora o reprovado no vestibular buscava emprego em algum escritório. Imaginem quantos técnicos em contabilidade devia haver disponíveis. Quem empregaria alguém que tinha feito o curso científico?

Minha mãe, sempre muito pragmática no comando de sete filhos, teve então uma ideia audaciosa. "Por que tu não vais ao Colégio Jacob Renner? Lá podem estar precisando de professor." Havia na proposta de minha mãe duas fabulosas ousadias: a mais significativa, ela muito católica recomendar-me uma escola mantida pela Igreja Episcopal; é preciso recordar que o Concílio Vaticano II só começaria no ano seguinte, e o vigário católico da cidade negava a eucaristia aos pais que colocassem os filhos no Jacob Renner, que era uma escola gratuita. Professores católicos certamente mereceriam a excomunhão. A outra, o crédito que ela tinha no seu filho, admitindo que esse tivesse requisitos de ser professor. Mãe é mãe!

Na manhã de 13 de março fui ao Jacob Renner, sendo entrevistado pelo diretor Reverendo Ernst Bernhoeft, alma mater do Colégio. Não me lembro de que ele me perguntou, mas saí da escola com emprego. Lecionaria matemática nas duas $1^{\text {as }}$ e duas $2^{\text {as }}$ séries do curso ginasial. O curso ginasial era até a reforma do ensino imposta pela Lei 5692, de agosto de 1971, formado por quatro anos. O ginasial sucedia aos cinco anos do curso primário e era acessado mediante exame de admissão ao ginásio. As séries que me foram destinadas corresponderiam no sistema de hoje a $6^{\mathrm{a}}$ e $7^{\mathrm{a}}$ do ensino fundamental. Era uma segunda-feira. As aulas começariam na quarta-feira. Programei-me para ir a Porto Alegre no dia seguinte buscar meus livros, pois não trouxera ainda minha mudança, e preparar-me para a grande estreia. Todavia naquele mesmo dia ainda aconteceria algo inusitado.

No começo da tarde, batem na casa de meus pais, para onde eu retornara depois de meus fracassos no 
vestibular, - e perguntam pelo "Professor Attico!". Eu, não sem alta dose de atrapalhação, pois nunca fora assim antes chamado, respondo que era eu. "O Reverendo mandou este livro para o senhor preparar uma aula para hoje à noite, pois o professor do $3 .^{\circ}$ científico vai faltar!”. Engoli em seco e recebi o livro de Matemática do $3 .^{\circ}$ ano colegial, do Ary Quintella. Ainda tenho o livro de capa verde, com um desenho de uma função derivada na capa. Quem se preparava nervosamente para a estreia daí a dois dias, pariria a fórceps seu debute no magistério ainda aquela noite.

Lembro-me de que parti da João Pessoa, 1884, e desci a Oswaldo Aranha até perto da Estação da Viação Férrea, onde ficava o Jacob Renner, numa quase noite. Pelo caminho repeti várias vezes a aula sobre "números complexos" que preparava para alunos da mesma série que eu frequentara no ano anterior. Só fazia aos céus um pedido: que ninguém me perguntasse nada. Não recordo muito da aula, a não ser que sentia o suor pingar na minha espinha. Lembro o grupo. Eram talvez 10 alunos, dos quais mais de um no verão seguinte preparou o vestibular comigo. A história da falta do professor era blefe. Tornei-me, depois deste teste, professor da turma.

As aulas de matemática no ginásio eram mais difíceis do que aquelas do científico. Das aulas da noite para as da manhã havia uma diferença de seis anos de escolarização e eu fazia com muitas dificuldades essa transição. Ensinava álgebra no ginásio, mas eu não sabia fazer as abstrações exigidas. Tinha que ensinar o algoritmo da raiz quadrada (que hoje não sei mais fazer!) e imaginar problemas para contextualizar o assunto.

Logo na primeira semana a colega Maristela Lampert, por ter muitas aulas no colégio, passou-me as suas aulas de Ciências nas turmas de $3^{\mathrm{a}}$ e $4^{\mathrm{a}}$ séries do Ginásio, assim ministrava aulas nas quatro séries do ginasial. Lembro que nessas aulas de Ciências tinha que ensinar o aparelho reprodutor humano masculino e feminino para um bando de adolescentes inquietos. Logo em seguida, assumi as aulas de Ciências da turma do $1 .^{\circ}$ ano de magistério, onde havia talvez umas 20 moças e um rapaz e eu era quase vaiado quando me referia às alunas e não aos alunos; referir-se, como agora, a alunas e alunos, então, não era usual. Só viemos aprender isso com Paulo Freire muito depois.

Lecionava em uma das quatro séries do Ginásio e nas três do Científico [no capítulo seguinte conto como o "acaso" me fez professor de Química e quanto isso foi decisivo na escolha de fazer vestibular para outro curso], mais uma série do Curso de magistério. O Reverendo me dizia que meu salário era bem maior que o dele. Só lamento muito que então, não tivesse como hoje "meu diário" manuscrito; este só começou em 1985 e será muito útil quando na segunda metade desta história.

Tenho ainda muito a contar deste ano 1 de minha história, mas a proposta do tamanho dos capítulos não pode 
ser fraudada logo no primeiro. Assim, 1961 há de voltar aqui já no capítulo seguinte.

\section{8 [Excerto do capítulo: 1962 - Mais aluno, menos professor, $p .33$ a 38$]$}

1962 é o ano da abertura, em outubro, do XXI Concílio Ecumênico da Igreja Católica: o Vaticano II, que se estende até 1965 e terá muita importância no Ocidente, e pessoalmente me envolverá, principalmente por namorar uma menina de confissão luterana e enfrentar forte intolerância de minha mãe, a ponto de ela levar cartas recebidas por mim ao fogo. Nesse namoro talvez comecem meus estudos acerca das diferenças entre religiões e também minhas buscas de um ecumenismo. Isso depois marcará meu envolvimento muito intenso com as conexões entre a História da Ciência e a História das Religiões. Mas, 1962 começa com o professor que no ano anterior iniciava a sua trajetória como professor (também) de Matemática do $3 .^{\circ}$ científico, fazendo-se, mais uma vez, vestibulando e tendo como parceiros no preparo das provas alguns dos seus alunos.

Agora a opção de vestibular não era mais Engenharia. Os insucessos anteriores catalisados por ser incapaz de traçar uma parábola com tinta nanquim fizeram uma decisiva correção na trajetória de professor. Em fevereiro fiz vestibular na Faculdade de Filosofia para o curso de Química. Fui um dos três aprovados. A Josete Dani Sanchez e o Frater Afonso Alles, SJ eram os meus dois colegas. Uma vez fomos ao cinema os três. Parece que fomos assistir 'West Side History' e o Alles escondeu a batina em lugar estratégico para só tomá-la na volta. Tempos depois ele largou a batina em definitivo, e lembro que fui ao seu casamento em Florianópolis. Recordo que muitas vezes ia estudar no velho Colégio Anchieta, onde ele residia, e então me era oportunizado conversar com um sábio jesuíta doutor em Química, Pe. Matthias Schmitz, S.J. Era algo que me encantava muito. Em 1966, o Pe. Matthias celebrou meu casamento religioso. Guardo com carinho o livro "Bases teóricas da Química Orgânica" que muito usei enquanto professor e que conserva uma dedicatória de um dos mais brilhantes professores de Química da UFRGS.

O porquê da opção pelo curso de Química tem uma história. No ano anterior, em julho, aconteceu algo decisivo para que o professor amador que eu era se profissionalizasse. Havia, então, os exames de suficiências da CADES (Campanha de Aperfeiçoamento e Difusão do Ensino Secundário), do MEC. A CADES oferecia, em várias cidades brasileiras, nas férias, cursos intensivos de um mês para não licenciados, divididos em duas partes: conteúdo e didática. Vim para Porto Alegre e durante todo julho fiz o curso para professor de Matemática. Foi então que aprendi pela primeira vez algo de didática de sala de aula e também acerca de conteúdos de matemática para ensinar no Ginásio. Vencido o curso se fazia uma avaliação para verificar se 
tínhamos condições mínimas para continuar como professores. Os melhores eram aconselhados a fazer "exames de suficiência”. Fiz exames e fui aprovado. Ocorre que um colega meu que lecionava Química no Jacozinho, engenheiro químico (ou estudante de Engenharia), fez o mesmo exame e foi reprovado, tendo então a sua licença precária cassada. $\mathrm{Eu}$, como tinha obtido então registro de Matemática, assumi as aulas de Química das três séries do científico.

Este curso da CADES deve ter sido muito significativo para mim. No primeiro semestre de professor, anterior a esse curso, não fui nada mais que um repassador de conteúdos. Esse curso mostrou-me a necessidade de contextualizar o que eu ensinava. Claro que não operou milagre em um mês. Recordo que tive que dar uma aula durante o curso. Então procurei uma justificativa, ou melhor, um significado para ensinar raiz quadrada. Vale lembrar a pobreza de meu exemplo.

"Se tivermos uma área de $200 \mathrm{~m}^{2}$, na qual queremos construir um cercado para criar galinhas com quatro lados iguais, qual deve ser o valor de cada lado?” Realmente, na minha precária contextualização não havia nenhuma ideia acerca das dimensões da área no qual queria inserir meu cercado quadrado. Custei a aprender a fazer um ensino mais inserido politicamente. Nos anos que se seguiram, especialmente a partir do golpe de 1964 e a instauração da ditadura, eu era um ingênuo. Mais, um reacionário. Escudava-me numa pseudoneutralidade da Ciência. Lamentava a situação dos professores de Filosofia, Sociologia se comparados com as minhas facilidades, enquanto professor de Química, por poder passar um ensino asséptico.

A bandeira de um ensino mais séptico (menos asséptico) ou mais encharcado na realidade demorou, ainda, a ser levantada por mim; todavia, acredito que uma vez empunhada fiz escola com ela. Agora, quando escrevo este texto, quase meio século depois do ano que evoco, dou-me conta de o quanto mais uma vez estou desatualizado. Eu me reconheço um alienígena na Escola do final da primeira década do século 21. Qual o sentido das discussões que buscamos fazer com professores, quando eles são prisioneiros de apostilas que são compradas de grandes grupos que devem ser seguidas dentro de um fundamentalismo que faz inveja aos mais xiitas? Mais adiante isso será tema por aqui.

No relato de meu exame de suficiência em Matemática, que após o curso de um mês o MEC outorga-me o registro com valor de um licenciado, isto é a mesma certificação de quem fazia então um curso de quatro anos. Assim, me torno também professor de Química. A partir do segundo semestre, no meu primeiro ano de magistério, era professor de Matemática em duas primeiras e em duas segundas séries do ginasial e na terceira série do científico; de Ciências na terceira e quarta série do ginasial e na primeira série do curso normal e Química nas três séries do científico. Tinha um guarda-pó branco com o meu nome. Esta era, 
também, uma estratégia para me distinguir dos alunos do curso científico com idade muito próxima à minha.

Mas ser professor de cerca de três centenas de alunos em uma cidade que então deveria ter cerca de 20 mil habitantes era significativo. Isso representou a minha inserção na vida social da cidade. Passei a frequentar os bailes do "Riograndense", o melhor clube social da cidade. Havia então bailes memoráveis. Além dos "kerbs" que uma cidade com tradição alemã celebrava por ocasião do padroeiro da cidade - São João Batista -, a passagem de orquestras (lembro o nome de uma: Cassino de Sevilha) determinava bailes concorridos. Recordo também que o grupo de professores fazia incursões a bailes na região colonial do Vale do Caí. Certamente fazíamos sucesso como os da cidade que chegavam aos bailes na colônia. Então, já com mais de 21 anos, tentava, sem muito sucesso, os primeiros namoros.

Por neste meu primeiro ano de magistério viver intensamente a vida social da "metrópole do tanino no Brasil", arvorei-me a escrever crônicas em O Progresso, semanário local que recordo ver impresso a partir da composição de matrizes resultantes da juntada manual de tipos de chumbo, na redação e oficinas da Osvaldo Aranha.

Meu grande guru então era o Pedrinho. Em 2004, um pouco depois de sua morte, li uma notícia em jornal interno da UNISINOS, que provocou a seguinte mensagem: "Soube, pelo J. U., emocionado a notícia que o Centro de Ciência da Comunicação deu o nome de Pedro Pinto da Silva ao seu Auditório. A celebração, nominando assim um espaço nobre da Comunicação, é muito justa. Não convivi com o Pedro na UNISINOS, mas ele foi meu sábio parceiro, quando há 43 anos iniciava minha carreira de professor. Trabalhávamos juntos no então Colégio Jacob Renner em Montenegro. Ele já tinha alguns anos de casa e o chamávamos carinhosamente de nosso decano. Eu, como um iniciante, recém-saído do colegial, e ele me estimulava na minha iniciação que se fazia como professor de Matemática e Química no $3 .^{\circ}$ científico e também de Ciências nos cursos Ginasial e Normal. Foi também muito companheiro nas bonitas relações de amizade fora da Escola. Dele lembro especialmente a audácia, por 'desobedecer' as ordens do vigário católico da paróquia, antes do Concílio Vaticano $2 .^{\circ}$, e lecionar em colégio episcopal. Estou feliz em saber que agora ele é nome de Auditório." Recordo que o fundador do Jacozinho, Reverendo Bernhoeft, logo que chegou a Montenegro, pilotava um motociclo (ancestral das motos) onde estava escrito "Missionário" e, marcados pelo sectarismo católico, foi nos sugerido escrever em continuação “...do Diabo!”.

Miro imaginariamente uma foto de um time de vôlei dos professores do Jacob Renner. Nela está a evocação da única vez que entrei em uma quadra para jogar. Nem sei se ganhamos ou perdemos para um time de nossas lindas alunas do qual também tinha uma foto com ousados saiotes para uma escola episcopaliana. No time dos professores estão também o Pedrinho, o Mr. Robert, um missionário 
estadunidense, e, salvo engano, os dois irmãos Thomas (Hermeto e Cirilo). Procurei muito as duas fotos, mas não as encontrei.

Mas em 1962 não era tão plenamente professor como no ano anterior e nem tinha a vida social que antes contei. Com a minha aprovação no vestibular priorizei o Curso de Química, então pertencente à Faculdade de Filosofia da UFRGS. Transferi-me para Porto Alegre, onde morava desde 1958, com o lapso de um ano (1961). Passei a fazer parte de uma "república" de estudantes, na rua Olavo Bilac, em Porto Alegre, liderada pelo Blásio Hickmann.

Todavia, continuava viajando a Montenegro duas noites por semanas, para dar aulas de Química no Jacob Renner. Era um fazer exigente, pois neste meu primeiro ano de faculdade cursei com aprovação as quatro disciplinas indicadas (Complementos de Matemática, Física Geral e Experimental I, Química Geral e Inorgânica e Química Analítica Qualitativa). Pelos registros que tenho isso correspondia a cerca de 30 horas de aula por semana.

Ao final da tarde corria do Instituto de Química para Rodoviária, e de lá, de ônibus, por uma hora e meia, ia a Montenegro (cerca de $80 \mathrm{~km}$ de Porto Alegre). Dava 5 períodos de aula a cada noite. Pousava na casa de meus pais e no dia seguinte, às $6 \mathrm{~h}$, tomava o primeiro ônibus para Porto Alegre, estando às $8 \mathrm{~h}$ no Instituto de Física e no de Química para uma manhã e uma tarde de aulas.

Em outubro deste ano iniciei uma atividade que iria fazer parte intensa - e muito bem-sucedida - pelos 10 anos seguintes de meu ser professor: dar aulas em cursos pré-vestibulares. Ela começou no Curso Pré-Vestibular do Centro Acadêmico (da Faculdade de Filosofia da UFRGS) Franklin Delano Roosevelt. Tenho um atestado que comprova essa atividade, firmado em 4 de fevereiro de 1964 (às vésperas de o cursinho ser fechado pelo golpe militar de março) pelo Prof. Joaquim José Felizardo. O diretor do cursinho declarava que eu era "considerado pela Direção, como por seus alunos, professor exemplar, tendo demonstrado ser mestre de alta categoria, como pode ser atestado pelo inquérito realizado pelo Curso, entre o corpo discente". Um gostoso elogio para quem estava começando. Em outro segmento vou comentar essa faceta de professor de pré-vestibular em minha ação docente.

Assim, já aceno o quanto, nesta história que recém-iniciou, tenho por contar. Em 1962/65 sou um aluno do curso de Química se fazendo professor.

\section{9 [Excerto do capítulo: 1998 - Sobre fazer diários: também um colecionismo, p. 355 a 361]}

${ }^{4}$ Esta citação está no texto $O$ umbigo vitoriano, resenha do livro $O$ coração desvelado, de Peter Gay, elaborada por Nicolau Sevcenko para o Jornal de Resenha - Folha de S. Paulo, p. 8, 12 jun. 1999 .
"Nunca viajo sem o meu diário. É preciso sempre ter alguma coisa sensacional para ler no trem!" 
${ }^{5}$ A fonte é o Jornal de Resenha referido na nota anterior.

${ }^{6}$ FEYERABEND, Paul. Matando o tempo. São Paulo: Editora da Unesp, 1996.
Por que escrever diários? Confesso que não sei responder esta pergunta. Talvez se a modificasse para "Por que escrevo diários?" seria mais fácil a resposta. Seria simplista: porque gosto. Acho que, como gosto de ler diários e biografias e especialmente autobiografias, gosto de escrever diários. O historiador inglês, Sir Thomas Macaulay (1800-1859), ao ser perguntado sobre sua leitura favorita, confessou: "Nenhuma leitura é tão deliciosa, tão fascinante quanto a história minuciosa do 'eu' de uma pessoa". Nicolau Sevcenko ${ }^{5}$ acrescenta que Macaulay, muito provavelmente estivesse a se referir a si mesmo e ao seu hábito de ler e reler continuamente seu próprio diário.

Os diários, como os álbuns de fotografias, são para recordar momentos vividos. Manuseamos uns e outros para matar saudades. Diários e álbuns de fotografias são coleções de momentos de vida.

Talvez o "Nosce te ipso", que tanto ouvimos em nossa formação, tenha a ver com esta quase obsessão de escrever e nos ler com tanta frequência. É muito bom se ver e recordar o vivido, e parece que não há narcisismo nisso - e se houver, saberemos conviver com mais essa considerada desvirtude. Mas em diários também se escrevem fracassos e estes, nem sempre trazem boas evocações.

Aliás, sempre pensei que autobiografias estivessem intrinsecamente associadas a escrever diários. Li, há não muito tempo, a de Paul Feyerabend ${ }^{6}$, onde o admirado e contestado autor de Contra o Método nos mostra sua vida com dolorosa crueza, e lá vejo que, quando precisou responder a algumas interrogações sobre sua história disse: "Não é fácil responder a estas questões. Nunca escrevi um diário, não guardo cartas, nem mesmo de ganhadores do Prêmio Nobel, e joguei fora um álbum de família para dar espaço ao que então eu julgava serem os livros mais importantes" (1996, p. 11). Brinco, que meus biógrafos não terão o trabalho a que Feyerabend se referia, ou talvez, terão muito trabalho, pois deixarei muitos volumes de diários, muitos recortes de notícias, cartas, convites. São minhas memórias que aflorarão depois, mesmo que o destino mais apropriado de meus diários seja aquele indicado por Wilde na abertura destas reminiscências. Brincadeiras à parte, pergunto-me se uma neta ou um neto perderá tempo com estes legados. Por outro lado, quem de nós não gostaria de ter pelo menos uma carta de um avô ou de uma avó?

Mas, me parece claro que não escrevo diários para os outros. O meu mais assíduo leitor é, e certamente ainda serei, eu. Imagino sempre que a um tempo meus escritos serão bons passatempos, pelo menos para mim. Atualmente, em algum momento de folga me permito alguns exercícios. Olho o que fazia, por exemplo, há cinco ou dez anos. E, então, não fico apenas naquele dia, vou para frente e para traz dando-me conta de quanta coisa passa a ser possível de ser rememorada exclusivamente com auxílio de algumas anotações. Há um número muito grande de fatos e feitos dos quais não lembraria se não fosse o diário. 
Há não poucas situações em que meus diários já foram úteis para esclarecer circunstâncias. Recordo particularmente o meu não envolvimento em uma multa de trânsito, pois tinha elementos que me diziam que naquele dia nem saíra de carro ou até para esclarecer que determinada multa ocorrera quando emprestara o carro para determinado familiar. Mas, talvez, fundamentalmente escrevo diários para matar saudades. Parece que isso me dá sobejas razões para prosseguir entusiasmado no meu fazer. Afinal, parece ser decisivo rastrearmos o passado para melhor projetarmos o futuro, vencendo assim um nocivo presenteísmo.

Como escrever diários? Querer responder a esta pergunta é no mínimo pretensioso. Como se houvesse algumas normas e, agora, eu magistralmente as desfiasse ensinando ao leitor ou à leitora como escrever diários. Vou contar como eu faço. Se houver entre os que agora me leem mais dois ou três escrevinhadores de reminiscências cotidianas, muito provavelmente teremos mais duas ou três metodologias sobre a arte de escrever diários. É muito provável que alguns leitores poderão apontar outros textos acerca do assunto. Sonho até que minha descrição poderá ajudar a catalisar novas descrições acerca deste quase mister.

Neste 2015, estou no $32 .^{\circ}$ [atualizado para este texto] volume ininterrupto de meus diários. Tenho quase uma dezena de diários anteriores, com interregnos. Lamento existirem esses períodos vacantes. Refiro-me aqui, apenas, aos volumes sequenciais que tenho desde $1 .^{\circ}$ de janeiro de 1984 . Em maio deste 2010 pretendo completar dez mil dias sem nenhuma data que tenha ficado sem algum relato. Essa não interrupção até o momento exigiu em algumas situações, registros em lugares nada ortodoxos, como em Centro de Tratamento Intensivo de hospital, ou descrições de passar por mais de vinte quatro horas em um leito suplementar em um grande hospital na Europa ou em momentos bem mais agradáveis como, por exemplo, quando fomos à cidade onde havia recém-nascido mais um neto, e uma alternativa mais prática e prazerosa que encontramos para passar a noite foi em motel, e claro que o fato - o nascimento do neto, é óbvio - mereceu um adequado registro no diário.

É fácil supor quantas descrições de alegrias e tristezas há nestes trinta e dois volumes já completos que coleciono - aqui a ação verbal é capital - em uma estante em minha biblioteca. Vez ou outra, os exibo a alguma visita, que os conheciam de referências e então os manuseiam, geralmente não sem admirações. Afortunadamente, há muito mais alegrias que tristezas. Entre as frustrações estão um descasamento, as tristezas nas dores das mortes de meu pai e de minha mãe - está sepultada num dos momentos mais indeléveis para quase todos deste século 21: aquele 11 de setembro de 2001, quando do esboroamento das torres do WTC - de dois irmãos, dos quais um até hoje sinto não ter podido participar do sepultamento por estar no exterior - e de não poucos amigos. Alegrias há muitas: 
um readolescer com uma nova relação amorosa que teve uma linda celebração de casamento depois de dezoito anos, o doutorado e também os gostosos meses madrilenos de pós-doutoramento - narrado um pouco no capítulo 2002 -, os livros publicados, os sucessos pessoais e profissionais dos filhos e das filhas, o advento do avonado e depois ser bisavô quase seis anos depois, agora já com registro de seis netos, participações em concursos literários, com sucessos e insucessos - estes mais numerosos que aqueles, ou a reconquista de um local maravilhoso de morar e muitas, mas muitas mesmo, outras situações. Também há o registro de centenas de palestras que dei nesses anos, geralmente com logo da instituição que me acolheu. Envolvimentos em pleitos e resultados eleitorais têm registros tanto entre as alegrias quanto entre as tristezas. Também as decepções políticas amargam algumas páginas.

A cada ano (desde 1984) os volumes são formados por agendas, de preferência, em que cada dia já tem impressa a data, com um mínimo de informações. Há uma exigência importante: que o sábado e o domingo não sejam de apenas $1 / 2$ página, como a maioria das agendas. Assim, na agenda escolhida para o ano a escolha me envolve desde o começo de dezembro.

Tenho comigo uma "obrigação contratual" de em cada dia se registrar a página diária. O melhor modelo é aquele que após cada domingo tenha uma página em branco, para receber colagens ou registros suplementares da semana. Sem fazer aqui comerciais, as agendas das Edições Paulinas ou da Paulus são usualmente as preferidas, até porque, sem poder precisar explicações, gosto de saber qual é o santo do dia. Como elas são dirigidas ao clero, as páginas de domingo são inteiras. Como curto usar canetas de diferentes cores, a textura do papel interfere muito na escolha.

Usualmente a página diária não é escrita toda no final do dia. Há, na sua maioria, um ou dois microrregistros por dia. O primeiro deles faço geralmente na abertura do dia, registrando expectativas ou sonhos com a chegada do fim de semana. Às vezes, quando tenho uma saída à noite, que promete merecer posteriores evocações, deixo um espaço para registro do evento noturno, para o dia seguinte. Assim, cada página comporta os relatos do dia, não sendo feitos todos necessariamente no dia. Mas repito, há registros a cada dia.

Muitas páginas têm colagens de resenhas de filmes assistidos, um ingresso de teatro ou uma passagem de ônibus, ou um cartão de embarque de viagem aérea, ou ainda, um bilhete especial recebido. Certas datas, como por exemplo, cada dia 25 - que marca o início de uma bonita história de amor que em abril de 2016 completará 348 meses ou 29 anos - tem uma chamada especial. Não é sem razão que se diz que estes diários são práticas de adolescentes e é muito bom adolescer quando já se é, há um tempo, setentinha. 
${ }^{7}$ Então as páginas do diário foram insuficientes para "minha escritaterapia". Para superar as limitações de espaço, escrevi o livro Uma rapsódia prostática - mais um daqueles inéditos -, que já teve versões domésticas usadas por alguns em momentos singulares.
Há ainda, em cada um dos volumes anuais, algumas informações mais gerais. Por exemplo, no último dia de cada ano o diário recebe um termo de encerramento, que pode incluir um balanço anual. Assim, há alguns volumes que registram comentários dos livros lidos no ano, dados de principais viagens, algumas aquisições significativas.

Não faço seleção sobre o que registro. Escrevo sobre bônus e ônus. Tenho o privilégio de viver situações usualmente agradáveis. As coisas menos boas são raras, mas quando estas ocorrem também ganham registros. Como não tenho leitor imediato, não há porque censurar certos escritos; assim, muitas vezes escrevo sobre coisas mais íntimas. Quando tive câncer, há mais de onze anos, houve relatos de apreensões, especialmente acerca de possíveis sequelas ${ }^{7}$. Hoje, quando isso é relido, tenho uma gostosa sensação de vitória.

Há relatos de algumas tensões que ocorrem na Academia, especialmente dos quatro anos em que fui coordenador de um Programa de Pós-Graduação e tive muitas dificuldades em ser um líder em um céu com muitas estrelas; nos registros há especulações acerca de radicais transformações que houve na Universidade onde trabalhava. Estas, todavia, não me ocupam muito. Poucas vezes redijo alguma informação sob forma cifrada, e como também não tenho desafetos (assim imagino e espero) não uso codinomes para me referir a alguém. Tenho muitas siglas, em geral para citar locais que ocorrem com frequência, que são identificáveis abreviadamente por economia de espaço. Assim, nestes tempos de diários já morei na OP, na VG, na SA, na LP e agora moro na MA que significa Morada dos Afagos.

Nestes vinte e oito anos houve muita evolução no escrever e no "fazer os diários", sendo, todavia, uma das poucas atividades escritas que ainda faço sem o uso do computador. Como está na frase que elegi para epígrafe deste texto, meu diário é uma peça inseparável em qualquer viagem. Ter um cartão do hotel colado quando faço o registro do dia tem sido útil para fazer uma nova reserva ou para voltar a contatar para saber se não foi localizado algo que esqueci. Viagens de férias já ganharam diários especiais paralelos, e sobre estes caberia um extenso relato sobre quantas madrugadas passei colando informações turísticas e fotografias. Tenho colecionado alguns volumes de nossas viagens à Europa, à África, à Ásia. De todas as viagens, as mais impactantes ainda são as que fizemos primeiro ao Peru e a Bolívia e depois ao México. Tenho redigido excertos a partir destes diários de viagens e sonho um dia enfeixá-los em forma de um livro de viagem.

E a "mania" de fazer diário é uma forma de colecionismo? Disse neste texto que coleciono - e a ação foi então sublinhada - vinte e sete volumes de diários em uma estante em minha biblioteca. Contei também como são construídos esses artefatos culturais. A resposta sim a esta pergunta poderá ser um sim mais enfático quando relatar o 
que "adorna" a maioria de cada um dos quase dez mil dias feitos registros de histórias.

Assim, talvez com a adesão de cada uma e cada um dos leitores deste texto se pudesse afirmar isso é fazer coleção. Eu pelo menos acredito na assertiva: a "mania" de fazer diário é uma forma de colecionismo.

\subsection{Excertos de algumas blogadas}

Desde 30 de julho de 2006 escrevi quase 3,1 mil edições no meu blogue. Há textos para escrever uma volumosa autobiografia. Dentro da concepção que dou à tessitura deste texto para a Revista Pedagógica da UNOESC tenho imensas dificuldades para fazer uma seleção de excertos de meus blogares por quase dez anos. Escolhi seis excertos. Poderia escolher sessenta ou seiscentos. Não vou justificar a escolha. Eles estão a seguir, com destaque à data e número da edição. Acredito que estes seis dizem algo de quem aqui tenta se autobiografar.

\subsection{Ano 8, 31 ago. 2013, 2529. ed.}

Estou, nesta manhã, retornando de Ribeirão Preto/ Guarulhos/Porto Alegre. Ontem, graças à fidalguia de colegas pude conhecer um pouco de Ribeirão Preto, imponente metrópole com 650 mil habitantes e, mais especialmente, o magnífico campus da USP, localizado em terras de uma antiga fazenda de café.

A palestra promovida pelo Departamento de Química da USP foi concorrida, mais de 120 pessoas de diferentes áreas. Muitas fotos e autógrafos. Estes são não foram mais numerosos porque $80 \%$ dos livros que trouxera na quarta-feira foram adquiridos em Araraquara.

Encerro agosto aqui na região central de São Paulo. Aditei ao rol de postagem deste blogue mais duas cidades: as duas últimas edições ocorreram em Araraquara e esta, em Ribeirão Preto.

Há quem diga que o mês que vive seu ocaso é $o$ mês do desgosto. Parece que, este ano, cumpriu sua sina. Tive o meu dissabor, que nem de longe se assemelha, por exemplo, aos daqueles que foram vítimas de dias diluvianos no Rio Grande do Sul, como contei aqui na quinta-feira. Tive desgosto? Sim, mas nada a abalar convicções. Curti o mesmo, por vários dias, antes de trazê-lo. Faço aqui e agora.

Chassot, o breve, bis. Há 20 anos, vivi meteórica passagem como diretor de uma importante escola particular de Porto Alegre. Se um dia for referido na história da mesma, a menção será "Chassot, o breve... não durou seis meses." No meu livro Memórias de um professor: hologramas desde um trem misto há um capítulo dedicado este episódio não muito glorioso de minha história.

Neste agosto repete-se algo parecido. A $1 .^{\circ}$ de março de 2013, a convite, fui contratado como professor de um 
Programa de Pós-Graduação em Educação. Enchi-me de entusiasmo. Teci sonhos. Refiz planos, mas não fraudei minhas convicções. Organizei seminário inédito, em um mestrado muito promissor, muito bem avaliado pelos participantes.

Em dias de julho, meus colegas e eu recebemos algo assim: "Como estamos finalizando o primeiro semestre, tendo em vista manter suas pastas atualizadas, solicitamos a entrega impreterivelmente até o dia 15/o7 de relatório da produção do semestre”.

Em minha resposta, após menos de cinco meses na instituição, enviei o relatório do qual está uma síntese ao final (no blogue transcrevi por extenso).

Meu relatório foi avaliado. Recebi aviso para comparecer à instituição, para ser demitido no mesmo dia em que uma professora amazonense me envaidecia, com esta mensagem publicada em uma rede social mensagem que recebeu dezenas de comentários:

Queridíssimo mestre Attico Chassot, é por ter sido contagiada por sua incansável tentativa de fazer alfabetização científica e por admirar, respeitar e acreditar em seu belíssimo trabalho, tens constantemente viajado comigo pelo interior do Estado do Amazonas por intermédio do 'Alfabetização Científica: questões e desafios para a educação', 'Sete Escritos sobre Educação e Ciência' e 'A Ciência através dos Tempos'. Satisfação imensa em tê-lo como um referencial em termos de alfabetização científica e poder disseminar suas ideias com os participantes do PCE FAPEAM! Forte abraço, Aldalúcia Gomes.

Argumento para demissão: meu perfil não tinha produção que o mercado exigia. Precisavam de produtores de artigos científicos publicados em revistas com impacto acadêmico. Eu, em cinco meses, não anunciara nenhum.

Hoje, na pós-graduação brasileira para os docentes há duas alternativas:

1) Sujeitar-se a ser "máquinas produtoras de artigos" que sejam publicáveis em revistas tidas como de nível excelentes, preferentemente estrangeiras, cuja produção gere impacto (= ser citado);

2) Candidatar-se a serem excluídos do sistema, por negar à Educação o status de mercadoria e centrar a sua produção acadêmica na disseminação da mesma à sociedade que financia a maior parte da pós-graduação brasileira, especialmente a área das Ciências Humanas.

Minha opção é a segunda alternativa. Opto por fazer uma Educação que não é aquela que narro em Chassot (2012b). Não consigo submeter-me à primeira. Por tal sou ferreteado como um improdutivo. Assim não sonego o acerto da decisão de quem me fez, uma vez mais, ser... Chassot, o breve. 
Síntese do Relatório do $1 .^{\circ}$ semestre de 2013

\section{1 - PUBLICAÇÃO DE LIVROS}

1 - Ensino de Ciências: Pontos e contrapontos [diálogos entre Nélio Bizzo e Attico Chassot, mediados por Valéria Amorim Arantes]. São Paulo: Summus, 2013, 192 p. ISBN 978-85-323-0891-7

2 - A Ciência é masculina? É, sim senhora! São Leopoldo: Editora Unisinos, 2013 (1. ed. : 2003) sexta edição ampliada e atualizada.

\section{2 - PREFÁCIOS}

1 - Um prelúdio para outro Ensino Médio prefácio mais orelha para Reestruturação do Ensino Médio: pressupostos teóricos e desafios da prática [AZEVEDO, José Clovis; REIS, Jonas Tarcísio (orgs)]. São Paulo: Fundação Santillana e Moderna, 2013, 192 p. ISBN 978-85-6348-915-9

2 - Um prelúdio, ou tentativa encantar-se com a docência prefácio e quarta capa para Ciências e Biologia: propostas para um continuado (re)iniciar [DUSO, Leandro; HOFFMANN, Marilisa Bialvo (orgs)]. Ijuí: EdUnijuí 2013, 320p. ISBN 978-85-419-0063-8

3 - Um prelúdio, ou tentativa de fazer de utopias, realidades prefácio para Guia do técnico de segurança do trabalho [BRASIL, Jairo]. São Paulo: Atlas, 2013, Prelo

4 - Uma isagoge em laudação a um manual prefácio do livro Manual de implantação de museus escolares BARCELLOS, Guy Barros]. Porto Alegre: Edipucrs, 2013, no prelo.

3 - CAPÍTULOS DE LIVROS

CHASSOT, Attico et al. Produção do conhecimento na Educação superior: uma perspectiva inclusiva. In LEITE, Denise; LIMA, Eliseth Gonzaga dos Santos. Conhecimento, avaliação e redes de colaboração: produção e produtividade na Universidade. Porto Alegre: Sulina. 2013, p. 348- 370. ISBN 978-85-205-0667-7

4 - PUBLICAÇÃO COM DISCENTE

BONIATI, Silvia Daiana Parussolo; CHASSOT, Attico. Avaliação da aprendizagem em sala de aula: a implantação da Progressão continuada. Trabalho submetido e aceito nos III Congresso Internacional de Avaliação e o VII Congresso de Educação promovido pela UNISINOS em outubro de 2013.

5 - SEMINÁRIOS: Três de 30 horas cada em Manaus, Frederico Westphalen e Canoas.

6 - DISCIPLINA MINISTRADAS: duas na graduação e uma no mestrado;

7 - PALESTRAS: Vinte uma em 10 cidades de 5 estados para cerca de 2.100 pessoas

8 - BANCAS: Oito em 5 cidades em 4 estados

9 - ORIENTANDOS: Sete: 2 doutorandos e 5 mestrandos em 4 instituições diferentes 


\subsection{Ano 9, 27 dez. 2014, 300o. ed.}

Hoje se completam três mil edições deste blogue (isto é algo como cerca de 30 livros de 250 páginas!). Mesmo que entenda que números redondos pedem celebração, não vou fazê-lo. Até aproveitarei o número 3000, que não tem nada de cabalístico (... e não é capicuo, muito menos primo!) para um anúncio. Como este não é nada trivial, preciso de preliminares.

Quase se completam 8,5 anos de blogares. Comecei em 30 de julho de 2006. Com exceção de um período, entre maio e outubro do ano passado, este blogue foi diário. Naquele período fui estimulado a parar. Era preciso proteger a saúde, diziam.

Defini um aperiodismo. Tive crises de abstinência. Primeiro escrevia uma vez ou duas por semana. Depois três ou quatro, a seguir cinco ou seis. Não aguentei... logo voltei a ser diário, como anteriormente.

Agora, eu defini que sairei de circulação. Decisão difícil? Sim. Maturada? Muito. Ninguém me estimulou a tal. Muito menos apoiou. Até porque existem algumas poucas pessoas para as quais antecipei meu propósito. Não foi/é uma decisão fácil. Também não consigo fazer uma síntese das muitas reflexões que fiz nestas últimas quatro semanas de dezembro, marcadas por um dicotômico: paro/não paro.

Mas, decidi. Vou parar!

Não sinto a sensação de fracasso ou impotência. A rapidação no sistema de absorver e de disseminar o conhecimento determinada pela Internet é galopante. Em 2006, quando comecei, ter blogue era estar na vanguarda. Hoje, apenas oito ou nove anos depois parece algo anacrônico. Poderia trazer meia dúzia de exemplos. Cito um: quando comecei a blogar, ninguém lia em smartphone. Hoje poucos usam as plataformas de então. A diagramação, a extensão do texto e até o assunto requerem outras estratégias. Ainda há pouco vi um anúncio de um smartphone, para ser pago em 24 meses com a garantia de que em 12 meses de teria crédito para trocar por um novo. O desenfreado consumismo é veraz... e é voraz. Ele valoriza a informação. Desprestigia o conhecimento.

$\mathrm{O}$ acesso mestrechassot.blogspot.com não desaparece. De vez em vez, talvez coloque algo. Logo no começo do ano estarei partindo para o exterior em férias. É provável que surjam algumas anotações extraídas do diário de um viajor.

A decisão maior: o blogue diário desaparece. O escrevinhador continua com garra. Estou escrevendo um livro. Disse-me que precisava das horas em que blogava (veja-se, o tempo é passado) para dedicar-me a esta escrita. Bom mesmo será quando eu aprender a só usar correio eletrônico e assemelhados apenas umas duas horas por dia. Isso é uma meta AC 2015.

Obrigado a cada uma e cada um das centenas de leitores que amealhei. Um agradecimento muito especial aos 
meus estimados comentadores. Vocês foram sustentáculos. Agradeço por serem inspiração. Obrigado por não me fraudarem.

Termino lembrando uma maneira de dar tchau de minha infância: tocava-se a aba do chapéu, às vezes imaginária, se dizia: "Até um mais ver!". Assim: até outro mais ler!

\subsection{Ano 9, 31 dez. 2014, 3001. ed.}

E... já passaram quatro dias da histórica blogada número três mil. Primeiro devo dizer que de maneira aparente, estou resistindo bem às crises de abstinências. Não tive nenhum sintoma de recaída.

Parece que a decisão que anunciei aqui na última edição foi acertada. Sinto-a aprovada, de maneira muito empática por 19 comentários de meus queridos leitores. Isso é gratificante, especialmente se considerar que a edição no dia de sua postagem teve recorde de acessos dezembrinos [(434); 203 a mais que no dia 24, por exemplo] para um sábado no ciclo natalino, época usualmente mais fraco em termos de acessos a blogues e assemelhados. A última edição, além dos 434 acessos no dia 27 teve ainda 346 (dia 28) + 301 (dia 29) + 258 (até às 20 horas de ontem), assim com mais de 1,3 mil acessos.

Há comentários comoventes. Claro que muitos massagearam meu ego. Há soneto acróstico e edição especial de um blogue. Há amigos solidários que são muito presentes aqui. Há singelas afirmações de desconhecidos que dizem tudo em meia dúzia de palavras: "Não acredito, porém entendo, e que assim seja." Também há muitos exageros: "fica uma lacuna nos artefatos culturais que fazem a alfabetização científica".

Mas esta edição de hoje não é apenas para matar a saudades e dar uma blogadinha. Afinal prometi que, de vez em vez, o mestrechassot.blogspot.com daria sinal de vida. Afinal, em 100 meses (quase 8,5 anos) houve cerca de um milhão de acessos. Isso não se apaga com um palavrório como o contido na edição do último sábado, dizendo tchau.

Assim, aqui e agora, neste ocaso de 2014, agradeço a parceria em cada uma nas edições deste ano. Não vou oferecer destaque, mas houve edições históricas, nas quais realmente fizemos juntos um significativo adensamento da alfabetização científica. Por tudo isso: muito obrigado.

\subsection{Ano 9, 1.0 jan. 2015, 3004. ed.}

Nesta terça-feira a Gelsa e eu estamos partindo para uma viagem internacional. Vamos mais uma vez cruzar o Atlântico, rumo à Europa, destino mais usual de nossas viagens. Primeiro vamos a Berlin, aonde a Gelsa tem, por três dias, compromissos acadêmicos. Depois estaremos em férias, ainda em Berlin e depois uma semana na Polônia (nossa primeira vez neste país) e a seguir alguns dias na França. Voltamos em 3 de fevereiro. 
Em blogada anterior (7 jan. 2015) acatei a sugestão - mesmo que o blogue não seja mais diário -, de contar um pouco destes dias de viagens, em pelo menos cinco blogadas. Uma genérica (e preliminar) acerca de viagens - é esta de hoje - e quatro outras, uma de cada uma das quatro cidades que visitaremos. Assim, as emoções serão socializadas com excertos do conhecido diário de um viajor.

Quando, em 2012, publiquei Memórias de um professor: hologramas desde um trem misto, reservei um dos cinquenta capítulos para falar de minhas viagens internacionais. Hoje, pelos meus registros começo a minha $30^{\mathrm{a}}$ viagem internacional. Comecei tardiamente, mas depois que tomei o gosto, quase a cada ano fiz uma viagem internacional.

Comecei apenas em 1989. Fiz, então, a minha primeira viagem à Europa. Entusiasmado pela Gelsa, presenteei-me, pelo meu $50.0^{\circ}$ aniversário, com uma primeira viagem ao exterior. Estou subtraindo deste computo alguns cruzares de fronteiras, anteriores a 1989, em breves incursões a quatro países vizinhos (Argentina, Uruguai, Paraguai e Bolívia). Se computadas tais, a rigor, minha primeira viagem internacional, foi - ainda menino - nos começo dos anos 50s: fui com minha mãe e meu irmão Sirne, de trem desde Montenegro à Uruguaiana (como filho de ferroviário, quando meu pai estava de férias tínhamos passe livre nos trens da VFRGS), e então cruzamos a ponte internacional e fomos a Paso de los Libres, na Argentina. Recordo da conversão cambial, que exigia multiplicar por 1,80 , e eu logo vi a facilidade de multiplicar por dois e subtrair dois décimos. Compramos alfajores e passas de uva, também farinha de trigo (que se dizia ser mais pura que nossa) e azeite de oliva.

As narrativas de viagens foram, em priscas eras, instrumentos para mostrar aos outros aquelas terras conhecidas pelos poucos que se aventuravam em "arrostar mares nunca dantes navegados”. Entre estas são famosas as narrativas de Marco Polo, segundo alguns um personagem ficcional. Há, em muitas culturas, ainda em tempos hodiernos, o hábito de se valorizar esse gênero literário. Parece que, entre nós, esse nicho de escrituras de viagens ainda não goza de muita aceitação. Há alguns títulos publicados que nos levam a devaneios e viajar com o autor.

Eis um informe da $1^{a}$ viagem: jul./ago. de 1989: Entre $1 .^{\circ}$ de julho e 7 de agosto fizemos aquilo que faz um marinheiro de primeira viagem (eu, no caso, pois a Gelsa já havia morado na Europa): estivemos em onze países viajando de trem. Começamos em Paris, fomos a Bruxelas, Amsterdam, Berlin (ainda dividida entre a República Federal da Alemanha e a República Democrática Alemã), Colônia, Bonn, Luxemburgo, Heidelberg, Munique, Viena, Salzburg, Praga (na então, Tchecoslováquia, antes da separação em dois países), Zurique, Lucerna, Veneza, Florença, Roma, Vaticano e Paris. Foi maravilhoso ver "ao vivo" muito do que havia conhecido em minhas leituras e 
estudos de geografia. A França, que foi ponto de chegada e de partida, festejava então o Bicentenário da Revolução Francesa. O primeiro contato com Paris se deu na rue Gay-Lussac, que para um professor de Química era significativo. Foram dias de emoções muito fortes.

As outras 28 que medeiam aquela primeira e a $30^{\mathrm{a}}$ que começa hoje foram muito diversas. Mesmo que a Europa tenha sido a preferida houve outras memoráveis. Assim, na América já estive em doze países: Argentina (várias vezes), Uruguai, Paraguai, Chile, Bolívia, Peru, Colômbia, Equador, Venezuela, Guiana Inglesa, México (três vezes) e Estados Unidos. Na Europa já amealho além dos onze países da $1^{\mathrm{a}}$ viagem outros onze: Portugal, Espanha, Reino Unido, Grécia, Turquia, Bulgária, Croácia, Eslovênia, Dinamarca, Suécia e Rússia. Na Ásia estive em 8 países: Tailândia, Cingapura, Malásia, China, Hong Kong (em 1997, ainda não pertencente à China), Israel, Palestina e Jordânia. Na África, em quatro: Marrocos, África do Sul, Tunísia e Egito.

A Polônia, onde devemos estar na próxima semana, deverá ser o $47 .^{\circ}$ país que visitarei. Sobre esta viagem que começa nesta terça quero compartilhar quatro edições nos próximos dias, iniciando com Berlin. Obrigado pela companhia. Encerro lembrando que o "Bom viajante não é o que não sabe para onde vai, mas o que sabe de onde veio!"

Lin Yutang [(1895-1976) Escritor e filologista chinês nascido em Changzhou. Estudou nas Universidades de Shanghai, de Harvard e de Leipzig. Foi professor na Universidade de Beijing. Viveu quase meio século nos Estados Unidos e sua significativa obra literária significou uma ponte entre vazio cultural existente entre o Ocidente e o Oriente].

\subsection{Ano 10, 30 jul. 2015, 3066. ed.}

Esta é uma edição comemorativa. Há dias eu me referi a este 2015 como annus arduus, então fui lembrado que na História, por algumas situações, há annus terribilis, ou para usar uma expressão mais popular períodos de inferno astral. Diz-se que, a um ano terrível sucede um annus mirabilis, ou um ano maravilhoso ou um tempo em que gira a roda da fortuna. Porém ainda há cinco meses para passar este 2015 de vacas magras.

Hoje recordo (não comemoro) os nove anos deste blogue. Comemoração, por ora me parece insípida ou sem graça. Mais recentemente, eu sinto que o blogue (não seu editor) não vai bem. Houve algumas estratégias não bem-sucedidas para curá-lo. Em maio de 2013 se fez perdas. Depois de 6,8 anos de blogares diários, optei, então, por edições semanais. A abstinência teve gosto amargo. Primeiro, cumpri a decisão. Depois a frequência foi aumentando. Meio ano depois a periodicidade voltou a ser diária. Em 27 de dezembro do ano passado, quando cheguei à edição 3.000: novas modificações. Então, eu defini que sairia de circulação. Decisão difícil? Sim. Maturada? Muito. 
Tinha razões: A rapidação no sistema de absorver e de disseminar o conhecimento determinada pela Internet é galopante. Em 2006, quando comecei a blogar era estar na vanguarda. Hoje, apenas nove anos depois parece algo anacrônico. Poderia trazer meia dúzia de exemplos. Cito um: em 2006, ninguém lia em smartphone. Hoje poucos usam as plataformas de então. A diagramação, a extensão do texto e até o assunto requerem outras estratégias.

O desenfreado consumismo é veraz... e é voraz.

Ele valoriza a informação. Desprestigia o conhecimento. Não vou aderir liminarmente a Umberto Eco que, há dias, afirmou: "a internet deu voz a uma multidão de imbecis". Mas, parece que faltam cada vez mais pessoas que olhem de maneira crítica o que leem e também o que escrevem.

O acesso mestrechassot.blogspot.com não desapareceu. De vez em vez publico algo. Esta é a edição 3066. Desde que deixei de ser diário passaram sete meses, assim há uma frequência aproximada de duas edições por semana. Hoje não entendo como mantinha um blogue diário. Fica, por ora, o propósito de manter este ritmo. Mesmo sabendo que não está sendo fácil, hoje, sustentar duas edições por semana. Estou em um ritmo maior de outros escritos. As exigências acadêmicas aumentam.

Sigo com o propósito de vez em vez postar algo. Como fiz, por exemplo, em janeiro quando trouxe excertos do diário de um viajor de Berlin, Varsóvia e Cracóvia ou, ainda, durante o primeiro semestre, comentei mais de uma dezena de viagens profissionais. Obrigado a cada uma e cada um dos meus queridos leitores que seguem prestigiando este blogue. Começamos, hoje, o ano DEZ. Façamos isso, e tudo o mais, na expectativa de tempos muito possivelmente melhores.

\subsection{Ano 10, 22 set. 2015, 3083. ed.}

No dia 3 de agosto, quando assisti a Valter Hugo Mãe, no Fronteiras do Pensamento ouvi algo que caiu naquela coxia do cérebro que, de vez em vez, se faz presente a uma espiadela. O escritor português contou que, com muita frequência lhe perguntam por que não faz doutorado em literatura. Disse em sua resposta: "sou objeto de teses, como iria conviver na Academia com aqueles de quem sou sujeito".

Não sei explicar as razões pelas quais a resposta me fez interrogante. Posso assegurar que, desta vez, não pequei por inveja, algo muito frequente em mim quando ouço acerca de sucesso de escritores.

Na manhã desta terça estou numa banca de qualificação de Daniela Regina Resende no Programa de Pós-Graduação: Processos Socioeducativos e Práticas Escolares, do Departamento de Ciências da Educação da Universidade Federal de São João del-Rei. A Daniela, orientanda do Professor Dr. Paulo César Pinheiro, traz a exame "A interação 
de professores com as narrativas híbridas do sítio Ciência na Comunidade: efeitos e desdobramentos".

Por estas maravilhas da tecnologia (e também por um dito contingenciamento de despesas que encolhe as universidades) não estarei, fisicamente, naquela cidade que desde abril de 1985, me evoca um pedreiro em um interminável fechamento tumular, quando do sepultamento de Tancredo Neves. A banca ocorrerá por Skype ou pelo Facebook.

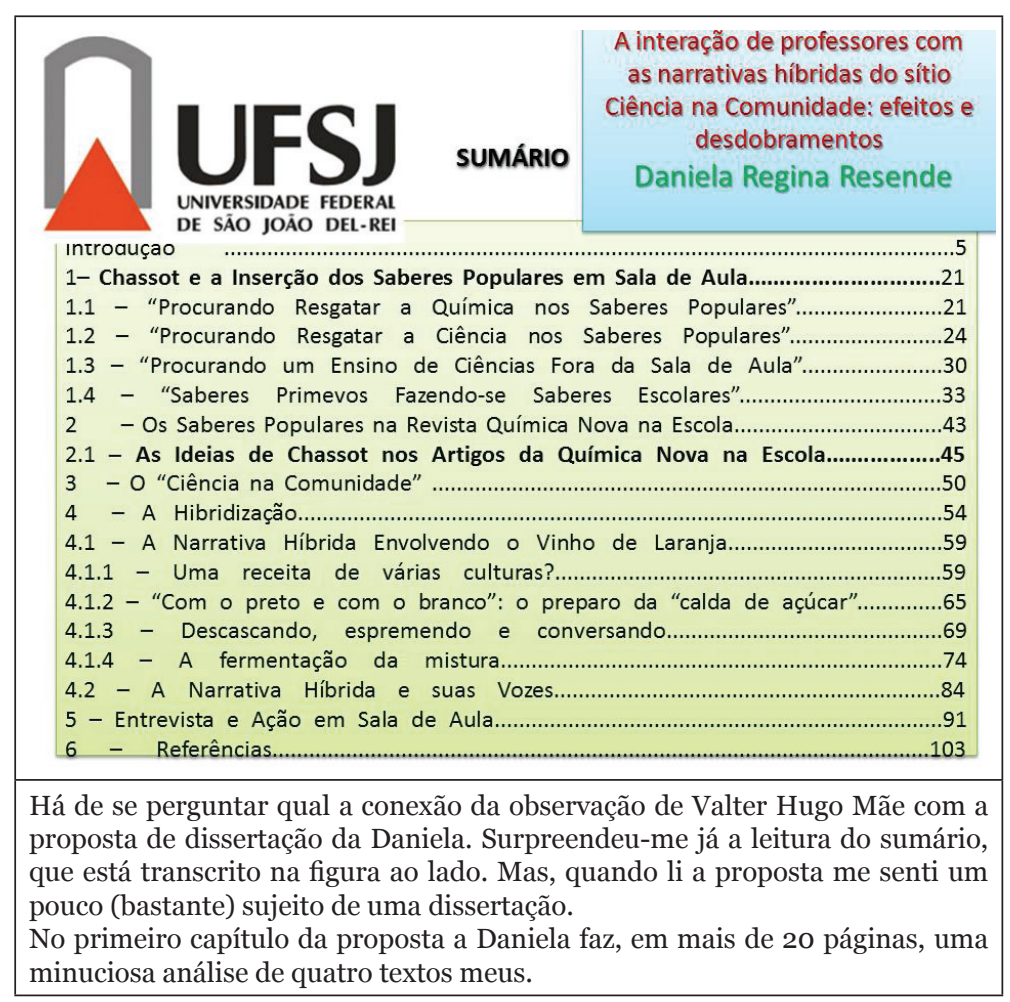

O primeiro é de A Educação no Ensino de Química [Ijuí: Editora Unijuí, 1990]. Talvez um dos primeiros livros de Educação Química escrito no Brasil.

Ao analisar um dos capítulos deste livrinho de 118 p. Procurando Resgatar a Química nos Saberes Populares, ela escreve "o décimo primeiro capítulo do livro [...] é o único do livro a tratar do ensino de Química por meio de saberes populares. É um texto de seis páginas, que vem 'mostrar uma linha de trabalho relativamente nova na área de Educação Química: o resgate de saberes populares'. Tudo indica que esta seja a primeira publicação em livro sobre este tema feita no Brasil" (Proposta, p. 21). Pois passado um quarto de século o tema já rendeu teses de doutorado, dissertações de mestrado, monografias de especialização, trabalhos de conclusão de cursos...

$\mathrm{Na}$ proposta está transcrito algo que eu escrevera na p. 104, em 1990: "A proposta que se defende implica na necessidade de resgatar a Química que está inserida na realidade física e social vivenciada pelos alunos (ou em outras realidades) e analisar com eles, de forma dialógica, os diferentes significados atribuídos e as diferentes formas 
de construção do conhecimento" (Proposta, p. 21). Outros textos são do Alfabetização científica: questões e desafios para a Educação (2001) e do Sete escritos sobre Educação e Ciências (2008) são analisados no primeiro capítulo.

No segundo capítulo da proposta a Daniela analisa sete artigos da Revista Química Nova Na Escola, de 2000 a 2013, de diferentes autores e procura nestes as "ideias de Chassot". A Daniela escreve:

[...] todos os sete artigos encontrados mencionam, de certa forma, a inserção dos saberes populares em sala de aula como uma prática para promover a valorização dos mesmos e a sua transformação em saberes escolares, assim como foi sugerido nos quatro textos de Chassot descritos no capítulo 1. Os artigos propõem trabalhos que, além de apoiarem a inserção dos saberes populares em sala de aula, orientam os professores na realização de práticas pedagógicas que busquem a inter-relação entre os saberes populares e os saberes formais ensinados na escola, promovendo uma mudança significativa no ensino de ciências. (Proposta p. 49).

Trouxe apenas pequenos excertos da Proposta. Ela espraia-se por várias páginas fazendo tessituras de ideias que se vem disseminando na Educação Química brasileira. Sinto a importância de minha contribuição. Este é um orgulho que me entusiasma a continuar estes fazeres. Um agradecimento muito reconhecido ao Paulo César e à Daniela. Será bom estar com vocês esta manhã em São João del-Rey.

\subsection{Desvelando uma fortuna crítica:}

Começo por relatar que até há muito pouco tempo não sabia o que era "Fortuna crítica", Aliás, para fazer este texto procurei muito sobre o tema; encontrei pouco. O Priberam, meu dicionário preferido não se refere à locução. O Aulete diz: "Fortuna crítica: o acervo de críticas sobre obra publicada”.

Recordo ter visto pela primeira vez a expressão na página oficial de Moacyr Scliar (1937-2011). Agora, voltei e encontrei como porção destacada da página onde estão relacionado escritos sobre o escritor gaúcho. Vi o termo traduzido do português para o inglês como: critical essays. Há alguns dias recebi uma mensagem que me alegrou. Abri uma pasta nos meus arquivos: Fortuna Crítica. Ela abre com a mencionada mensagem. Amealhei mais alguns dizeres sobre mim. Parte dos mesmos, adito a esta autobiografia. 


\section{Fortuna crítica}

"Prezado Mestre Chassot, boa tarde.

Meu nome é Lucas Pessoa, sou biólogo, especialista em Gerenciamento Ambiental e mestrando do curso de História da Ciência pela PUC-SP. Estou lhe escrevendo em primeiro lugar pela admiração ao seu trabalho muito antes de ingressar nos estudos pós-graduados em História da Ciência.

Atualmente tenho 31 anos, mas a primeira vez que vi seu livro A Ciência através dos tempos (ainda sem a possibilidade de contatá-lo via e-mail) eu tinha aproximadamente 15 anos. Na época fui apresentado ao livro por um querido tio meu, Jairo Alves Pereira, pesquisador do Gref na USP e também aficionado em História da Ciência.

Mas não era qualquer história. Ele sempre mencionou a importância na consideração aos percalços vividos pelos pesquisadores como peça fundamental na construção de uma história provável e não apenas o traçar de uma linha contínua e triunfante das descobertas sucessivas até o presente glorioso: o auge do conhecimento. Coisa muito bem elaborada em seu livro e também no artigo que acabo de esbarrar em minha prática docente.

Hoje sou professor de Ciências para o Ensino Fundamental I, II e Ensino Médio e reescrevendo meu planejamento anual procurei no Google (este oráculo fabuloso) o verbete 'alfabetização científica'. Estarrecido, li seu artigo Alfabetização científica: uma possibilidade para inclusão social e verifiquei em suas colocações mais do que a explicação que buscava, mas também muito da leitura que pretendo traçar em minha tese de mestrado.

Pesquiso atualmente sobre a ideia de progresso que permeou o cenário científico e político brasileiro em meio à instalação do parque industrial de Cubatão em São Paulo. E as ideias positivistas marcam muito bem o período.

Não tenho ao certo uma questão a fazer, doutor. Não tenho nem mesmo um pedido.

Somente um relato de minha admiração por seu trabalho e como o acaso me levou duas vezes distintas ao seu nome em todos estes anos."

Atenciosamente,

Lucas Pessoa.

Professor de Ciências e Biologia. Pós-Graduado em Planejamento e Gerenciamento Ambiental pelo CRBio-01/Mestrando em História da

Ciência pela PUC-SP CV: http://lattes.cnpq.br/9817466741382709 
Maurício Façanha, 28 de agosto de 2015 0o:16 "É sempre uma honra e um prazer imenso poder desfrutar deste nobre 'missionário da Ciência', principalmente no IFRN, onde pude colaborar com a implantação da Licenciatura em Química. Que tenha sido apenas o primeiro encontro em terras potiguares..."

Susie Gameleira, 29 de agosto de 2015 19:39

"Foi uma honra sem tamanho ter conhecido uma pessoa que tanto tem a nos ensinar."

Odisséia Gaspareto, 30 de agosto de 2015 21:10

"Caríssimo Chassot,

Para nós foi uma honra recebê-lo em nosso estado e principalmente em nosso evento. Com certeza aprendemos muito com seus ensinamentos e com sua experiência. Para os que tiveram a sorte de conviver com o senhor além das palestras, constatou que sua grandeza não se resume em seu trabalho, mas na pessoa incrível que o senhor é. Obrigada por nos permitir aprender mais da química da vida!"

Um afetuoso abraço.

Odisséia Gaspareto.

Márcio Dadox, 30 de agosto de 2015 21:29

"Professor Chassot,

Obrigado pelas palavras, pelo ensinamento. Amanhã, ao entrar em sala, falarei aos meus alunos da honra que tive em acompanhá-lo nesses poucos momentos, mas os quais levarei por toda a minha vida.”

Um grande abraço,

Márcio Bezerra.

Ayla Márcia Cordeiro Bizerra, 31 de agosto de 2015 17:53

"Querido professor Chassot,

Mais que uma honra em tê-lo em terras potiguares, foi de uma alegria e satisfação imensuráveis! Feliz demais por tê-lo acolhido tão bem. Anseio em poder vê-lo palestrar mais uma vez.

Muito obrigada por tudo, por proporcionar momentos únicos em nosso evento."

Um grande abraço repleto de carinho.

Profa. Dra. Ayla Márcia Cordeiro Bizerra - Química, Coordenadora do Curso de Licenciatura em Química - IFRN, Campus Pau dos Ferros. 
Ulysses Vieira, 1. ${ }^{\circ}$ de setembro de 2015 10:34

"Querido Chassot, boa noite!!

Que bom que chegou bem em casa e com disposição para logo cedo voltar ao trabalho. Sem sombra de dúvida a história da nossa instituição e da nossa semana de química ficou marcada com a sua sabedoria... foi muito rico passar esses dias com você. Fico muito feliz em saber que agora fazemos parte de sua história... desde muito que o autor/educador CHASSOT faz parte da minha história, mas agora, além disso, o ser humano, o cidadão brasileiro... Toda energia do mundo para continuar transformando o mundo em um lugar melhor para se viver.

\author{
Abraços, \\ Ulysses Vieira. \\ Professor de Química do Ensino Básico, Técnico, \\ Tecnológico, \\ IFRN - Campus Pau dos Ferros.
}

Prof. Dr. Edson Schroeder, FURB, Blumenau, 26 de setembro de 2015

"Estimado professor Chassot, foi um imenso prazer tê-lo aqui conosco. O senhor é um destes gigantes citados por Newton. Obrigado pelos ensinamentos, pela sabedoria. Esperamos seu retorno, muito breve.

\title{
3.18 Agradecimentos em teses e dissertações
}

Ao meu querido e grande Mestre Chassot que compartilhou comigo momentos de muitas alegrias e incertezas, que soube entender as minhas dúvidas e o meu tempo. Parafraseando Newton, afirmo que se consegui ver tão longe é porque me apoiei nos ombros de um grande gigante, Mestre Chassot. Muito obrigada!

Silvia Daiana Parussolo Boniati, no agradecimento de sua dissertação, A avaliação da aprendizagem como uma possibilidade de emancipação no regime da progressão continuada Frederico Westphalen, RS, julho 2014

Ao meu querido orientador Prof. Dr. Attico Inácio Chassot pela sua sabedoria, amor, dedicação e infinita paciência com minha inexperiência e ansiedade de aprender. Seu exemplo de dedicação a esta bela profissão de educador me inspira e estimula a seguir este caminho. Obrigado por fazer parte da minha existência e por me ajudar a evoluir espiritual, emocional e intelectualmente!

Sabrina Guerreiro Caldeira

Prevenção de bullying: o que responsáveis por escolas de Porto Alegre têm a dizer? Dissertação no Mestrado Profissional de Reabilitação e Inclusão do Centro Universitário Metodista do IPA 
Agradeço ao meu querido orientador, mestre Attico Inácio Chassot, que me desafiou e auxiliou nas incertezas de um caminho, agora conquistado. Obrigado pelas sabedorias compartilhadas, pela atenção e por se manter compreensivo nos momentos de espera desta pesquisa, a você todo o carinho e admiração.

Camila Guidini Camargo

Diálogos e/ou monólogos interculturais quando da presença indígena na universidade Frederico Westphalen, março, 2014

Ao Prof. Dr. Attico Inácio Chassot que não se negou em me orientar, mostrando-se sempre disponível e atencioso. Mesmo sabendo que não seria tarefa fácil, pelas condições geográficas que não permitiriam um contato mais direto, com paciência e presteza conseguiu dar valiosas contribuições para que este estudo saísse do casulo e se transformasse nesta TESE. Sinto-me privilegiada de sua orientação e amizade;

Célia Maria Serrão Eleutério

O Diálogo entre Saberes Primevos, Acadêmicos e Escolares: potencializando a formação inicial de professores de Química na Amazônia Tese no Programa de Pós-Graduação em Educação em Ciências e Matemática - PPGECEM/REAMEC da Universidade Federal de Mato Grosso, Parintins/ Manaus, 20 de fevereiro de 2015

\section{Um peregrino pela ciência.}

Nesta semana esteve em Belém, pela sétima vez (ou mais) nos últimos dez anos, o prof. Attico Inácio Chassot, um químico gaúcho, de nome tão incomum (para nós, nortistas) quanto a vida acadêmica assumida após aposentação da UFRGS: circula por todo o Brasil, e por vezes Brasil afora, em vilegiaturas rápidas, proferindo palestras, orientando e examinando teses.

Prefiro considerar, mais coloquialmente, que o professor Chassot se transformou num peregrino, integralmente comprometido com a nobre missão de discutir e difundir um dos temas que mais lhe é caro: a ciência. Segundo ele, ensinar a linguagem da ciência foi o que mais se propôs a fazer nos 53 anos de magistério, que nem a aposentadoria compulsória fez refluir. Esse polímata dos pampas, que aos 74 anos de idade continua em sala de aula, já publicou doze livros, entre os quais A Ciência é masculina?, já na 6. ${ }^{\mathrm{a}}$ edição, proeza de fôlego num mercado editorial tão volúvel e restrito como o brasileiro. O texto busca contribuir para que tenhamos uma sociedade menos desigual quanto às diferenças de gênero. Outro de seus livros, Alfabetização Cientifica: questões e desafios para a educação, cujos direitos autorais são doados permanentemente para o departamento de educação do MST, também já está na $6 .^{\mathrm{a}}$ edição. 
Sua última publicação enveredou pela memorialística ao fazer um ajuste de contas com seu próprio passado, no instigante Memórias de um professor, onde ele revisita sua infância (passada entre Santa Maria e Porto Alegre, em ambiente ferroviário) e passeia pela evolução do Brasil, destacando pontos referenciais que nortearam, para o bem ou para o mal, o desenvolvimento ciclotímico de nosso país. Além da divulgação da ciência por meio dos livros, mantém um concorrido blog onde fala de ciência e de outras linguagens que leem o mundo natural e cotidiano.

Em suas blogadas, Chassot tem aprofundado senso crítico a respeito de tudo e de todos - mormente quando o assunto é a política - e aproveitado para divulgar a diversidade cultural do país, pouco conhecida dos brasileiros. No caso paraense, sua admiração beira a fantasia e seu prazer pela gastronomia alcança, segundo o próprio, a gulodice, embora contida. Mas, paralelamente à admiração pela rica e ameaçada natureza amazônica, o professor Chassot é ácido na avaliação que faz dos gestores despossuídos do zelo necessário em conservar tanta beleza, concebida e desprezada. No caso do campus universitário do Guamá, por exemplo, suas palavras são generosas ao considerá-lo um dos mais bonitos espaços acadêmicos que conhece (e ele conhece muitos, no Brasil e no exterior), misturando natureza e arquitetura num rico espectro. Mas faz ressalva e não deixa passar despercebida a miséria enquistada pela explosão demográfica do bairro que cerca o campus da UFPA. De todas as capitais brasileiras, o professor Chassot só não conheceu ainda Macapá e Rio Branco, o que poderá acontecer a qualquer momento, tantos são os convites que enchem sua disputada agenda, onde sempre existe uma vaga para frequentes viagens ao exterior, junto com sua Gelsa, companheira de afetos e de ocupação.

Numa de suas visitas ao Pará, fez palestra em Bragança e, durante dois dias, conheceu de perto essa importante região pioneira na colonização do Estado. Nesta atual visita a Belém, o prof. Attico Chassot atendeu convite da Rede Amazônica de Educação em Ciências e Matemática, lotou o auditório e encantou o público. Eis mais um nome expressivo que se encanta e divulga a região amazônica.

Artigo semanal do jornalista e sociólogo José Carneiro, professor aposentado da UFPA publicado em 25 de maio de 2014, em $O$ Liberal, de Belém, jornal líder em circulação no estado do Pará, desde 1968. 
O poeta Jair C. Lopes, de Florianópolis, um muito presente comentarista de meu blogue, já me dedicou muitos sonetos e limeriques:

Soneto-acróstico

\section{Ao cisne que não canta}

Um dia, diz Chassot, ele pendura a chuteira Mas não hoje, existe lenha a queimar ainda Como encerrar devoção de uma vida inteira A menos que, de alguns valores prescinda?

Num canto, existe cisne a guardar seu canto Talvez, aguardando aquela hora derradeira Onde novos desafios apresentem o encanto De fazer esse mestre deixar a atual cadeira.

Enquanto houver vida eu afirmo, há vontade Como Chassot mostra encarar essa jornada Inda que muitas vezes, contra corrente nade.

Seja nesta tão conhecida, ou noutra estrada Nosso Attico Chassot como tonsurado abade Estará dando cartas de maneira apaixonada. JAIR C LOPES 27 de março de 2015

Após bloguear em muitas cidades O mestre está cansado de verdade A página que era diária Agora é hebdomadária Entretanto com a mesma qualidade.

JAIR C LOPES 29 de maio de 2013.

\subsection{Algo inédito}

Todos os textos que amealhei até aqui já tiveram, em algum momento, circulação, mesmo que alguns muito restritos. A maioria circulou no blogue ou são excertos de livros ou artigos. Este texto de encerramento, escrito em junho de 2013 perde agora seu ineditismo. É fácil sentir porque o desengaveto agora, cerca de 2,5 anos de sua escrita. Quero antecipar que a situação agora (outubro de 2015) parece muito melhor.

\subsubsection{Uma rapsódia parkinsoniana}

Esta tessitura se faz em três movimentos: o primeiro, une ouverture, na qual há um anúncio nada trivial; o segundo, uma pavana, que tem compassos lúgubres, marcados por dois motes: incurável e degenerativa; terceiro, um gran finale, onde se constrói utopias para transmutá-las em realidades. 
Une ouverture: o denso e fruído maio de 2013 ia para seu ocaso. Mas ele tinha promessas. No dia 30, feriado (ou dia santo: Corpus Christi) a Gelsa e eu iriamos avonar. Viajaríamos com a Maria Clara e a Carolina, duas de nossas netas, em busca do Castelo de Pedras Altas.

Maio sábias reflexões. Estas convidavam mais a travar do que acelerar. No dia 13 tomei uma decisão que se fazia com perdas. Depois de 6,8 anos de blogares diários, opto por edições semanais. A abstinência tem gosto amargo, mas traz liberdades fugazes. É uma abolição como fora aquela do ocaso do Império, em um mesmo 13 de maio.

O diário manuscrito já no seu $30 .^{\circ}$ volume se faz fastidioso. A caligrafia esmaece. As linhas desalinham. As letras se apequenam. Resisto à tentação de abandoná-lo... Afinal, trinta anos não se aposentam.

O que eu sentia? Parecia que poderia responder com duas letras: ML. Eu me sentia Marcha Lenta. Em tudo. Para não ser exagerado: Um ML em quase tudo. Descer de um carro em ML. Colocar o cinto de segurança em ML. Afivelar a cinta em ML. Colocar os sapatos em ML. Meus 45 minutos de leitura de jornal pré-Academia parecem que a cada dia encolhem (isto é: leio menos). No digitar parece que não houve alteração: sempre fui (e sou) um ML modelo galinha catando de milho.

Há, todavia, fazeres que continuavam me gratificando e nos quais a ML era esquecida: Aulas e palestras. Aquelas ocorrem prazerosas na graduação e em três programas de pós-graduação. As palestras já somavam nove em maio. Elas me rejuvenescem. Ou, são o ópio que mascaram mazelas?

Mas parecia que algo não estava bem. Eu, renitente a médicos, chegando a viver meses sem buscá-los, tinha no dia 28, uma sexta consulta em maio. Antes: dermatologista, cardiologista, hematologista (nem sabia que existia esta especialidade clínica), urologista, oftalmologista. Agora, um neurologista.

Chega a esperada terça-feira, dia 28. Terças-feiras, neste semestre, são usualmente tranquilas, com duas aulas de Teorias do Desenvolvimento Humano à tarde e duas à noite. Uma consulta neurológica nervosa entre as aulas desfigura a última terça-feira do mês.

A tarde chuvosa se fez noite prematuramente. Nem sempre os horários agendados se ajustam com os que programamos. Isso aumenta a tensão.

A Gelsa, em 1999 com perspicácia, me empurrara a exames. Estes determinaram que, precocemente, fosse diagnosticado um câncer em fase inicial. Isso possibilitou, em tempo, uma cirurgia radical. Assim, há quase 15 anos sou câncer-free. Em maio de 2013 tinha um prognóstico. Isto ocorria com uma nova e recente especialização da Gelsa, em outra área orientada pelo doutor Google.

O prognóstico gélsico, na tarde-noite de 28 de maio de 2013, se faz diagnóstico. Sou portador de (Mal de) Parkinson. Mesmo tido como um pré-diagnóstico, esqueci a preposição. 
Uma pavana: Eu tenho Parkinson. Algo dramático. Assim, como em novembro de 1999 eu conjuguei, na primeira pessoa do presente a locução verbal: ter câncer, de repente, esperando condução, numa Avenida Independência engarrafada eu dizia, só para mim, algo indizível, inimaginável, impensado antes: "eu tenho Parkinson".

Logo em seguida eu parto meio estonteado ao Centro Universitário Metodista do IPA e a Gelsa vai a uma farmácia para que eu pudesse iniciar o tratamento e passa em minha casa para buscar o material para aquela noite ir a Erechim. Os atrasos me impediram de passar em casa. A Gelsa apanha-me no IPA, para deixar-me na rodoviária a 5 minutos da partida do ônibus. Também no trânsito ela sabe ser heroína.

Então, silente no ônibus, acredito que tenha "caído a ficha". Sentia uma imensa tristeza. Mesmo que o médico houvesse dito que "não se morre de Parkinson, mas com Parkinson". Chegado de madrugada ao hotel escrevi para Gelsa. Como resposta, ela insone, me chama. Conversamos. Aliviei-me.

O primeiro dia depois do laudo foi pesado. Recebia as atenções de colegas a URI de Erechim; todavia sentia-me qual Zumbi. A tarde na banca parecia que enrolava.

À noite havia uma palestra. Era meu debutar depois do diagnóstico. Primeiro dei uma entrevista a um canal de televisão, diante de um auditório lotado. Mas quando subi ao palco e olhei para mais de 200 pessoas pensei: vou desmaiar e cair. Na décima palestra do mês de maio parecia o menininho que no primeiro ano primário, tinha que declamar uma poesia no aniversário da madre. Encorajei-me. "Já tens Parkinson há meses! Já estás tomando medicação desde ontem! Não vais cair!”. Superei-me.

Voltei a Porto Alegre. No feriadão fizemos um turismo familiar com a Clarissa, o Carlos e duas netas. A busca do Castelo de Pedras Altas fez-se mítica. Voltamos no sábado. Parecia que esquecera a nova (para mim) doença.

Na manhã de domingo, dia 2 de junho, pela primeira fez fiz aquilo que Gelsa já fizera há duas semanas: criei coragem e fui ler sobre Parkinson. Parecia que estava lendo sobre mim: micrografia, dificuldades de fechar botões, lentidão física, perda de olfato.

Decisões foram tomadas. Ouvi a orientação médica: diminuir por ora as viagens, especialmente as mais distantes, como duas mensais em que viajo mais de seis horas a Frederico Westphalen na noite de quinta-feira, trabalho três turnos na sexta-feira e retorno à noite para Porto Alegre, com aulas, às vezes, na manhã de sábado.

Viver com qualidade de vida era preciso! Era isso que queriam aquelas e aqueles que me querem bem. Era isso que eu queria.

Um gran finale: O terceiro movimento desta rapsódia tem um final vibrante majestoso. Sua composição começa dia 11 de junho, duas semanas depois da consulta do dia 28 de maio, quando houve um pré-diagnostico. 
Mais uma vez, entre as aulas da tarde e da noite de Teorias do Desenvolvimento Humano, há agendada uma reconsulta com o neurologista. Seria a ratificação ou a retificação de um laudo. Tinha a companhia da Gelsa e da Clarissa. Estava apreensivo com possível atraso no atendimento, em vista das aulas da noite. Tudo dava certo. Diferente da primeira vez fomos recebidos no horário.

Então, uma cena inesquecível para mim: da recepção pelo médico até seu consultório há uma caminhada de uns 5 metros. Fui em frente e ele, a Clarissa e Gelsa atrás. Não tive (por que não me lembrei) nenhuma preocupação com as passadas, que são indicadores sintomáticos de Parkinson. Mas elas foram decisivas. O médico assentou-se a nossa frente com sorrisos. O sorrir era um laudo. Ele vira e externava o acerto e a eficiência de duas semanas de medicação.

Aqui algo singular! Era muito bom que se ratificasse o diagnóstico. Caso não fosse Parkinson - tratável e controlável - os sintomas que eu demostrara (e o tempo verbal já se fez passado) prognosticariam outras enfermidades muito mais graves.

Faço a seguir considerações acerca da medicação que estou tomando. Prolopa ${ }^{\circledR}$ BD comprimido de $125 \mathrm{mg}$. Princípio ativo: cada comprimido de Prolopa $₫$ BD contém $100 \mathrm{mg}$ de levodopa (L-dopa) e $28,5 \mathrm{mg}$ de cloridrato de benserazida (equivalente a $25 \mathrm{mg}$ de benserazida).

Não sou farmacêutico nem médico, logo o que trago aqui a seguir é apenas a satisfação da curiosidade de alguém que se viu ajudado por uma medicação. Não estou fazendo recomendação - muito menos - prescrição. Os dois parágrafos seguintes são um pequeno excerto transcrito da extensa bula do medicamento:

A dopamina, que age como neurotransmissor no cérebro, não está presente em quantidades suficientes nos gânglios da base, em pacientes parkinsonianos. A levodopa ou L-dopa (3,4-diidroxi L-fenilalanina) é um intermediário na biossíntese da dopamina. A levodopa (precursora da dopamina) é usada como uma pró-droga para aumentar os níveis de dopamina, visto que ela pode atravessar a barreira hematoencefálica, enquanto que a dopamina não consegue. Uma vez dentro do Sistema Nervosos Central (SNC), a levodopa é metabolizada em dopamina pela L-aminoácido aromático descarboxilase.

Após sua administração, a levodopa é rapidamente descarboxilada à dopamina, tanto em tecidos extracerebrais como cerebrais. Deste modo, a maior parte da levodopa administrada não fica disponível aos gânglios da base e a dopamina produzida perifericamente frequentemente causa efeitos adversos. É, portanto, particularmente desejável inibir a descarboxilação extracerebral da levodopa. Isso pode ser obtido com a administração simultânea de levodopa e benserazida, um inibidor da descarboxilase periférica. 
Uma síntese de/para leigo: a dopamina é responsável pela ativação de sinapses (=ligações) cerebrais. Deficiências da mesma determinam que o cérebro não emita comandos (ou o faça de maneira deficiente) para o corpo executar com competência certas ações do corpo. Esta é uma das características do parkinsonismo. Ocorre que se houver reposição de dopamina, esta não consegue vencer barreiras para chegar ao cérebro. Assim, para reposição da mesma é usada uma droga (L-dopa) que consegue chegar ao cérebro e ali se converter em dopamina. Para inibir que esta transformação ocorra antes de chegar ao cérebro a medicação consiste numa mistura de L-dopa com benserazida, que inibe a transformação (indesejada) da L-Dopa em dopamina antes de esta chegar ao cérebro.

Assim, quando escrevo essas memórias, já ao final de julho, com dois meses de tratamento. Com a reposição de dopamina (pela ingesta de três vezes ao dia de Prolopa) e uma sessão semanal de fisioterapia (e as continuadas 4 sessões semanais de academia, duas das quais com um educadora física exclusiva) estou me sentindo muito bem. O que anunciava no final do primeiro movimento quando escrevo esse majestoso gran finale parece apenas um pesadelo que ocorreu fugaz. Agora há apenas uma meta: seguir rigorosamente a proposta de tratamento, diminuir um pouco alguns compromissos para ter cada vez mais um viver com qualidade de vida.

\subsection{Posfácio}

Com a atualização de uma entrevista, a trazida de recortes de um livro de memória, a juntada de excertos de um blogue, com o ensaio de uma fortuna crítica e trazendo uma revelação muito pessoal, espero ter cumprido a tentativa de autobiografia. Foram pinceladas trazidas com o objetivo que estas me autobiografassem. Releio o texto para encaminhar aos Editores da Revista Pedagógica UNOESC; percebo que meu esboço precisa de uma moldura.

Falei do professor de 1961, contei de meus diários, falei de blogares, exibi-me na Fortuna Crítica, mas não falei do cidadão brasileiro Attico Inácio Chassot que em o6 de novembro de 1939 nasceu em Estação Jacuí. Mostro-o um pouco. Vivo em Porto Alegre, há quase 60 anos, destes cerca da metade morando sozinho. Sou casado, de papel passado, com Gelsa Knijnik, há 28,5 anos. Ela mora $5 .^{\circ}$ andar, no mesmo prédio que eu. Nós só moramos juntos quando fizemos pós-doutorado em Madrid.

Eu sou um latifundiário urbano, pois moro no $7 .^{\circ}$ e $8 .^{\circ}$ andares, uma residência com o carinhoso nome de Morada dos Afagos, em uma rua que em outubro se tinta de roxo com a florada de vetustos jacarandás. No oitavo andar, além do gabinete e de parte de minha biblioteca, há externamente jardins onde tenho três palmeiras, amoreira, pitangueira, jabuticabeira, araçazeiro, butiazeiro e uma gostosa parreira. Há também uma fonte com uma roda 
d'água com lindas carpas. Tenho redes nas bibliotecas e nos jardins. Curto-as, pois 'A rede é a vasilha de dormir que mais se assemelha ao útero materno'. Esta frase, do poeta Manoel de Barros, colhi no aeroporto de Cuiabá. Vivo muito bem e me deleito em ter aqui as minhas horas de produção e de lazer. No Rio Grande do Sul, mais que declinar a religião é importante assumir-se a paixão futebolística: sou um gremista, que na vida não chegou a ir dez vezes a uma partida de futebol.

Tenho dois filhos e duas filhas, que me deram 4 netas e 4 netos. No total são dez netos, pois as duas filhas da Gelsa deram-me dois netos.

Ler e escrever são minhas paixões. Estudar em suma: É salutar, desafiarmos para respondermos a esta pergunta: "No Oriente não ocorreu revolução científica porque com estar no mundo por influência de filosofias orientais não teve exigências de uma Ciência marcada por certezas?" ou "A ocorrência de revoluções científicas no ocidente pode ser creditada a maneira cristã de estar no mundo?” Talvez, uma síntese que poderia ser tema de uma significativa tese doutoral: "É a presença de um livro sagrado (Torá, Bíblia ou Corão), resguardado por uma ortodoxia religiosa, que se fez substrato para revoluções científicas?”. Afinal, não é, por exemplo, a matemática do livro que tem valor frente à etnomatemática.

Como argumento a tese: "É a presença de um livro sagrado (Torá, Bíblia ou Corão), resguardado por uma ortodoxia religiosa, que se fez substrato para revoluções científicas?" poderia se dizer que as quatro maiores revoluções científicas tiveram suas certidões de nascimento exaradas por livros que não apenas abalaram o mundo, mas receberam aceitação e garantiram uma disciplinarização marcada por uma ortodoxia.

Neste ano de 2015 diminui as minhas atividades acadêmicas. Em 30 de junho deixei de lecionar na URI de Frederico Westphalen. Leciono desde 2006 no Centro Universitário Metodista IPA. Tenho atualmente duas disciplinas na graduação e dois seminários na pós-graduação. Minha atividade acadêmica mais curtida é a disciplina que leciono na Universidade do Adulto Maior, nas tardes de segundas-feiras.

Considero-me um afortunado. Em termos de bens materiais tenho tudo que desejo ter. Orgulho-me que todas minhas posses têm origem no meu ser professor. Nada recebi de herança, produto de jogo ou dinheiro mal havido.

Além de minha casa, meu bem mais precioso é a minha biblioteca de cerca de 4 mil volumes. Entristece-me pensar que talvez a quase totalidade desse acervo terá destino não muito nobre.

Não coleciono frustrações. Talvez só tenha uma (ou pelo menos aquela que é maior): a minha magna dificuldade de expressar-me oralmente em outro idioma. A minha incapacidade de falar Inglês já foi causa de inúmeras perdas, especialmente, acadêmicas. Já tentei muitos "cursos" 
de Inglês e também de Alemão. Não tenho uma explicação consistente para isso. Levanto uma hipótese: nasci no começo da 2. ${ }^{\mathrm{a}}$ Guerra Mundial. A língua materna de meu pai e de minha mãe era o Alemão e este, então, era proibido no Brasil. Assim, meus pais falavam entre eles um idioma que era interdito aos filhos. A “outra" língua' sempre foi algo proibido. Não sei se ainda vou superar esta frustração.

Mesmo que espose a máxima "Na minha idade o futuro é o presente" penso em vários prazeres que futuro não me concederá. Por exemplo, quando conto historinhas a Betânia, que ainda não fez três anos, que me visita quase todas as manhãs de domingo, fico triste quando sei que não verei ela chegar à Universidade. Mas a vida já me deu tantos privilégios... e isso me conforta e me dá gana de viver plenamente ainda mais.

\section{REFERÊNCIAS}

CHASSOT, Attico. Memórias de um professor: hologramas desde um trem misto. Ijuí: Editora Unijuí, 2012a. 501 p. ISBN 978-85-7429-986-O

CHASSOT, Attico Vende-se tabaco, perfume importado, Educação e camiseta de marcas, p. 67-82, In: ARAUJO, C.M.M.; POLIDORI, M.M.Análise dos sistemas de Educação Superior no Brasil e em Portugal. EdiPUCRS / Editora Universitária Metodista, 2012b. ISBN 978-8599738-19-1

MLODINOW, Leonard. Subliminar: Como o inconsciente influencia nossas vidas. Zahar Editores. Google Play Livros, 2013, p. 68, 